\title{
Lidar profiling of aerosol optical properties from Paris to Lake Baikal (Siberia)
}

\author{
E. Dieudonné ${ }^{1, *}$, P. Chazette ${ }^{1}$, F. Marnas ${ }^{1}$, J. Totems ${ }^{1}$, and X. Shang ${ }^{1}$ \\ ${ }^{1}$ Laboratoire des Sciences du Climat et de l'Environnement (LSCE), CEA/CNRS/UVSQ, Gif-sur-Yvette, France \\ *now at: Laboratoire de Physico-Chimie de l'Atmosphère (LPCA), Université du Littoral, Côte d'Opale, Dunkerque, France
}

Correspondence to: E. Dieudonné (elsa.dieudonne@univ-littoral.fr)

Received: 7 September 2014 - Published in Atmos. Chem. Phys. Discuss.: 11 November 2014

Revised: 10 March 2015 - Accepted: 10 April 2015 - Published: 4 May 2015

\begin{abstract}
In June 2013, a ground-based mobile lidar performed the $\sim 10000 \mathrm{~km}$ ride from Paris to Ulan-Ude, near Lake Baikal, profiling for the first time aerosol optical properties all the way from western Europe to central Siberia. The instrument was equipped with $\mathrm{N}_{2}$-Raman and depolarization channels that enabled an optical speciation of aerosols in the low and middle troposphere. The extinction-to-backscatter ratio (also called lidar ratio or LR) and particle depolarization ratio (PDR) at $355 \mathrm{~nm}$ have been retrieved. The LR in the lower boundary layer $(300-700 \mathrm{~m})$ was found to be $63 \pm 17 \mathrm{sr}$ on average during the campaign with a distribution slightly skewed toward higher values that peaks between 50 and $55 \mathrm{sr}$. Although the difference is small, PDR values observed in Russian cities ( $>2 \%$, except after rain) are systematically higher than the ones measured in Europe $(<1 \%)$, which is probably an effect of the lifting of terrigenous aerosols by traffic on roads. Biomass burning layers from grassland or/and forest fires in southern Russia exhibit LR values ranging from 65 to $107 \mathrm{sr}$ and from 3 to $4 \%$ for the PDR. During the route, desert dust aerosols originating from the Caspian and Aral seas regions were characterized for the first time, with a LR (PDR) of $43 \pm 14 \mathrm{sr}(23 \pm 2 \%)$ for pure dust. The lidar observations also showed that this dust event extended over $2300 \mathrm{~km}$ and lasted for $\sim 6$ days. Measurements from the Moderate Resolution Imaging Spectrometer (MODIS) show that our results are comparable in terms of aerosol optical thickness (between 0.05 and 0.40 at $355 \mathrm{~nm}$ ) with the mean aerosol load encountered throughout our route.
\end{abstract}

\section{Introduction}

The quantification of the aerosol radiative forcing still suffers from large uncertainties, making aerosols the dominant contribution in uncertainties on the anthropogenic influence on climate (IPCC, 2013). To improve the performance of climate models, observations are needed in order to provide better constraints from the regional to the global scale. Large observational networks such as the Aerosol Robotic Network (AERONET; Holben et al., 1998), the Micropulse Lidar Network (MPLNET; Welton et al., 2001) or the Aerosol, Clouds and Trace gases Research Infrastructure Network (ACTRIS, formerly EARLINET; Pappalardo et al., 2014) provide the long-term measurement series needed to build a climatology of aerosol optical properties at the continental and global scales.

Complementarily, numerous large field experiments have taken place over the past years to monitor long-range transport of aerosols and cover areas that do not host dense observation networks like oceans, South-East Asia, Africa or Arctic: for instance the Aerosol Characterization Experiments (ACE-1, ACE-2, ACE-Asia; Bates et al., 1998; Raes et al., 2000; Huebert et al., 2003), the Indian Ocean Experiment (INDOEX, Ramanathan et al., 2001), the African Monsoon Multidisciplinary Analysis (AMMA; Lebel et al., 2010), or the Polar study using Aircraft, Remote sensing, surface measurements and models, of Climate chemistry, Aerosols and Transport project (POLARCAT; Law et al., 2015). During those field campaigns, airborne measurements have been performed, which offer observations on a larger scale than fixed ground-based stations.

On a smaller, regional scale, field experiments took place near large pollution hotspots like Mexico City, with the 
Megacity Initiative: Local And Global Research Observations project (MILAGRO, Molina et al., 2010), or Paris, with the Air Pollution Over the Paris Region project (ESQUIF, Vautard et al., 2003; Chazette et al., 2005), the Lidar pour la Surveillance de l'Air (LISAIR, Raut and Chazette, 2007) and the Megacities: Emissions, urban, regional and Global Atmospheric Pollution and climate effects, and Integrated tools for assessment and mitigation project (MEGAPOLI, http://megapoli.dmi.dk/; Royer et al., 2011). Aerosol optical properties have thus been extensively documented over western Europe and North America. Besides, Asia has drawn a growing attention as this region is becoming a larger contributor to aerosol anthropogenic emissions.

Conversely, very few measurement programmes exist over Russia, which for instance hosts only five stable AERONET stations while the country covers $11.5 \%$ of the world's dry lands and contributes to aerosol emissions through large forest fires and several pollution hotspots like Moscow (12 million inhabitants) or large industrial cities. Some measurement stations exist like the ZOTTO tower, located in the taiga $600 \mathrm{~km}$ northwest of Krasnoyarsk, where CO, particle concentration and aerosol optical properties have been measured continuously up to $300 \mathrm{~m}$ a.g.l. (above ground level) since 2006 (Heintzenberg et al., 2013). Vertical profiles of particle concentration and extinction up to $5 \mathrm{~km}$ were collected in the Tomsk region during an intensive flight campaign in 19861988, and then from monthly flights between 1999 and 2007 (Panchenko et al., 2012). At a larger scale, CO and particle concentrations have been measured during transcontinental flights in the framework of the Airborne Extensive Regional Observations in Siberia project (YAK-AEROSIB, Paris et al., 2010). However, most of the resulting observations took place in the free troposphere, and the flight plan was aimed towards the remote northern Siberian regions rather than the industrial cities of southern Siberia.

For other regions, and particularly for the industrial cities of southern Siberia, only space-borne instruments offer a regular coverage, for instance the Moderate Resolution Imaging Spectrometer (MODIS, e.g. King et al., 1992; Salomonson et al., 1989) or the Polarization and Directionality of the Earth Reflectance/Polarization and Anisotropy of Reflectances for Atmospheric Sciences coupled with Observations from a Lidar (POLDER/PARASOL, e.g. Deuzé et al., 2001) or the Cloud-Aerosol Lidar and Infrared Pathfinder Satellite Observation (CALIPSO, e.g. Winker et al., 2003 or Chazette et al., 2010). However, observations are limited by cloud coverage and by the satellite overpass time, so that ground-based observations are welcome to better document aerosols over Russia.

In June 2013, we performed the first road transect through Europe and Russia for aerosol profiling, with a $\mathrm{N}_{2}$-Raman lidar instrument embedded on a van going all the way from Paris to Lake Baikal, where the season of forest fires had begun. This campaign offers a unique snapshot of aerosol optical properties from western Europe to eastern Russia, which can be extrapolated in a broader climatological context through satellite observations. This paper aims at presenting the general variability of the aerosol nature, amount and optical properties along the journey. For this purpose, a systematic data processing is used, which precision is limited by the need to apply it both to the nighttime and daytime, noisier data. For this reason a finer characterization of the optical properties of the desert dust and biomass burning aerosols encountered in Russia is also presented, based on a few case studies using best quality data.

Therefore, this paper is organized as follows. Section 2 presents the itinerary of the campaign, the lidar instrument and the data processing methods used to retrieve the aerosol extinction, extinction-to-backscatter ratio or lidar ratio (LR) and particle depolarization ratio (PDR). Then, Sect. 3 presents the variability of aerosols along the journey, the particle nature being identified through the combination of the two intensives properties that are the LR and PDR. Section 3 also analyses the representativeness of the observations in regards to longer time series of space-borne measurements. Finally, Sect. 4 presents a few case studies on which it was possible to perform a finer characterization of the optical properties (LR and PDR) of the dust and biomass burning particles encountered during the route, and the origin of those particles is also discussed.

\section{Experimental setup and method}

\subsection{Itinerary}

The van carrying the lidar instrument departed from Paris on 4 June 2013 and reached Lake Baikal on 28 June. The trip was performed during the summer as it corresponds to the maximum of the wildfire season. After 28 June, fixed location measurements were performed on the shore of Lake Baikal, in Istomino village $\left(52.128^{\circ} \mathrm{N}, 106.287^{\circ} \mathrm{E}\right)$, and mobile observations were recorded during round trips between Istomino and Ulan-Ude city, $80 \mathrm{~km}$ southeast of the lake. Ground-based mobile measurements, though limited by battery power, could be conducted during most of the journey (during daytime). Fixed location measurements took place during most of the stop-overs (during nighttime) using local power supply. Intermissions were thus mainly due to rain showers and low-level clouds.

An overview of the van itinerary and of the lidar data availability can be found on Fig. 1. The journey went through a number of pollution hotspots: Paris, the Rhine Valley (Frankfurt), Berlin, Warsaw, Moscow, and several large and industrial Russian cities such as Nizhniy-Novgorod, Kazan, Ufa, Chelyabinsk, Omsk, Novosibirsk, Krasnoyarsk and Irkutsk. Regarding wildfires, three main vegetation types susceptible to produce biomass burning aerosols were encountered: first, temperate forest (visible in dark green on the MODIS image) dominate in the Baltic countries and western Russia, 


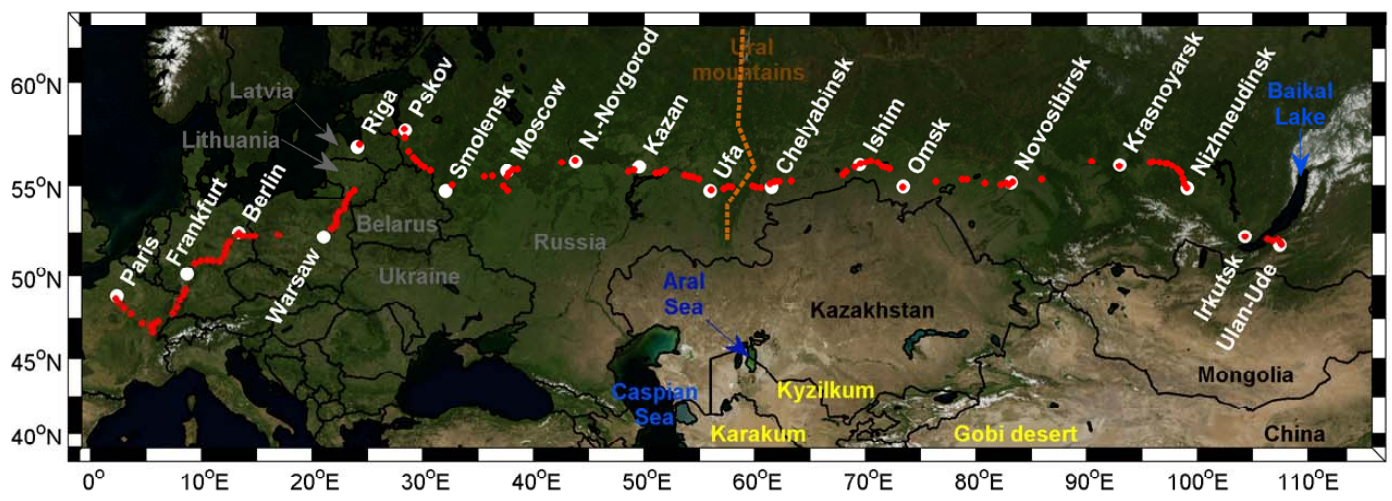

Figure 1. Itinerary of the campaign plotted over MODIS true reflectance image. White and red dots show, respectively the main cities or night stops of the van, and the location of lidar measurements.

then the vegetation turns into grasslands (lighter shades of green on the MODIS image) in the steppes of southern Russia (i.e. from Nizhniy-Novgorod to Omsk, except in the Ural Mountains) and finally boreal forest occupies all the eastern part of the journey (and the Ural Mountains between Ufa and Chelyabinsk). The map is extended down to $40^{\circ} \mathrm{N}$ in order to show the desert areas in the Caspian and Aral seas region where the dust particles observed during the campaign originated from.

\subsection{Instrumentation}

The lidar instrument used during the campaign is similar to the one previously described by Royer et al. (2011). It operates at $355 \mathrm{~nm}$ with $16 \mathrm{~mJ}$ pulse energy, and has three acquisition channels for elastic, perpendicularly polarized and $\mathrm{N}_{2}$-Raman backscatters. The signals were recorded with an initial resolution of $25 \mathrm{~s}$ (500 laser shots) and $0.75 \mathrm{~m}$, both in analog and photon-counting mode. During daytime, when the photodetectors are saturated by the sky background light, only the analog mode is used, whereas during nighttime the analog and photon-counting signals are merged to optimize both dynamic range and signal-to-noise ratio. After correction for the platform inclination (measured using a Xsens MTi-G GPS/inclinometer attached to the optical head) and after cloud screening, data are averaged over 5 or $30 \mathrm{~min}$ and $7.5 \mathrm{~m}$ in altitude. The $30 \mathrm{~min}$ averaging period was chosen because it makes the signal from the $\mathrm{N}_{2}$-Raman channel exploitable up to $700 \mathrm{~m}$, even during daytime, without mixing data recorded in too distant locations $(\sim 50 \mathrm{~km}$ given the speed limits).

The overlap functions of the lidar channels were assessed before the trip using horizontal profiles, when the lower atmosphere could be considered as homogeneous along the line of sight. Once attached to the van, it was not possible to tilt the lidar to retrieve the overlap function from a horizontal profile. It was instead checked using fixed observations below fair weather afternoon cumulus clouds (i.e. in a supposedly homogeneous boundary layer). The overlap function retrieved at different points of the journey (Riga, Irkutsk, Istomino) is remarkably similar, which confirms the optical stability and validates the well-mixed boundary layer hypothesis. Complete overlap is reached between 250 and 300 m a.g.l.

\subsection{Retrieval of the aerosol extinction and lidar ratio}

The signal from the $\mathrm{N}_{2}$-Raman channel is used to derive the aerosol optical depth profile supposing a constant value of 1 for the Ångström exponent (Ångström, 1964). Indeed, only sun-photometers provide Ångström values in the UV wavelengths (MODIS only provides the Ångström exponent between its 470 and $660 \mathrm{~nm}$ channels) and the van journey came close to only four AERONET stations over the $10000 \mathrm{~km}$. In the absence of experimental data, using an average value of 1 appears as a good compromise (the residual relative uncertainty was calculated to be less than $3 \%$ by Chazette et al., 2014). Also, molecular diffusion is corrected using extinction and backscatter profiles determined using a reference atmospheric density profile and a polynomial interpolation between the 40 levels of this profile (Royer et al., 2011 and references therein). Then, two data processing methods are used, depending on whether the Raman optical depth profile reaches an aerosol-free layer or not.

\subsubsection{Systematic data processing}

To analyse the variability of aerosols along the journey, we wish to obtain a set of aerosol optical thicknesses (AOT), LR (extinction-to-backscatter ratio) and PDR values using a systematic processing performed on the $30 \mathrm{~min}$ average profiles from the whole campaign (day- and nighttime). However, as the range of the $\mathrm{N}_{2}$-Raman channel is limited by the sky background light during daytime, this processing can only rely on a partial AOT between $300 \mathrm{~m}$ (complete overlap) and $700 \mathrm{~m}$ a.g.l. (range limit of the $\mathrm{N}_{2}$-Raman channel at noon). The partial AOT from the Raman channel serves to constrain the lidar ratio used in a standard Klett inversion 
(Klett, 1985), which is achieved through a convergent process described in Appendix A. When convergence is reached, the retrieved value corresponds to the average lidar ratio in the $300-700 \mathrm{~m}$ a.g.l. layer. The uncertainty on this value is estimated by propagating the photon noise on the lidar signal throughout the inversion process using a Monte Carlo algorithm. A profile is considered as "fully convergent", and the retrieved lidar ratio is considered as valid, only when all the 200 profiles in the Monte Carlo distribution are convergent.

Unfortunately, the partial AOT produced by the Klett inversion is very sensitive to the transmission by the upper layers, making convergence difficult when another aerosol type with a different LR is present above the constraint layer (e.g. an elevated dust or biomass burning layer or more frequently, moist aerosols near the PBL top). Consequently, only a small fraction of the profiles converge (see Sect. 3.1); for the others, it is necessary to choose an arbitrary LR value in order to compute the extinction profile, total AOT, and subsequently the PDR. In order to avoid introducing discontinuities in the AOT and PDR data sets between profiles that converged or not, the same LR value is used to invert all profiles through a standard Klett procedure. The chosen LR $(58 \mathrm{sr})$ is the mean value of the LR distribution obtained from the valid profiles (see Sect. 3.1).

\subsubsection{Case study data processing}

The case studies presented in Sect. 4 rely on fixed measurements, with longer time averaging. Nighttime observations, added to this longer averaging, make the $\mathrm{N}_{2}$-Raman channel exploitable up to a purely molecular layer (above $6 \mathrm{~km}$ a.g.l). In this case, a complete lidar ratio profile can be retrieved using either the standard Raman inversion method described in Ansmann et al. (1990) or a constrained Klett method similar to the one used for the systematic processing, but applied on a sliding window browsing the full altitude range. More details about both inversion processes are given in Appendix A. After the LR profile has been retrieved from the average profile over the whole period, it is used to process more frequent $5 \mathrm{~min}$ average profiles and invert the time-dependent extinction profile and AOT.

\subsection{Retrieval of the PDR}

The volumetric depolarization ratio (VDR) was determined following the procedure described in Chazette et al. (2012). It uses the transmission and reflection coefficients of the polarization separation plates as measured in the lab before departure, along with the gain ratio between the total and perpendicular polarization channels. The gain ratio value was calibrated using measurements obtained next to Lake Baikal during one night when the atmosphere was devoid of any elevated aerosol layer, featuring a purely molecular depolarization (with a value known from the filters bandwidth). Several tests carried on other days earlier during the campaign showed that the gain ratio varied by $5 \%$ at most, so that the value obtained from the Lake Baikal experiment was used during the whole campaign. The PDR is then computed as in Chazette et al. (2012). As the PDR is a physical parameter without meaning when there are few aerosols, its calculation is performed only for layers where the aerosol backscatter coefficient is at least $5 \%$ of the molecular backscatter (i.e. a scattering ratio above 1.05).

The error on the PDR is computed for each case presented in this study. The values and dominant sources of error are discussed in Appendix B. Below $4 \mathrm{~km}$ a.g.l, we find that, given the chosen scattering ratio threshold of 1.05, the relative uncertainty on the PDR is largely constrained by the uncertainty on the lidar ratio (i.e. between 8 and $20 \%$ - relative) for PDR values of $5 \%$ and above. Because of the error on the gain ratio, this relative uncertainty is always at least $7 \%$. For very low PDR values, the absolute uncertainty mostly depends on noise conditions, but remains above $0.2 \%$. More details and about the validation of these values via Monte Carlo simulation are given in Appendix B.

\section{Variability of aerosols along the transect}

This section is based on the $30 \mathrm{~min}$ average profiles inverted using the systematic processing described in Sect. 2.3.1. First, the distribution of LR values retrieved in the planetary boundary layer (PBL) is presented. Then, the spatial distribution of aerosols along the journey, analysed in terms of AOT and PDR, is discussed. A finer classification of the particle types encountered during the campaign is also proposed, based on the LR and PDR values retrieved in the PBL. Finally, the representativeness of the campaign period is assessed by comparison with longer time series of space-borne observations and ground-based sun-photometers.

\subsection{Distribution of lidar ratios in the boundary layer}

Data recorded during the whole campaign produced 547 cloudless $30 \mathrm{~min}$ average profiles. Because of sometimes insufficient aerosol load or due to the presence of elevated aerosol layers, only 106 profiles $(\sim 19 \%)$ can be considered as "fully convergent", i.e. they give the best quality LR values (see Sect. 2.3.1). Among those 106 convergent profiles, $30(\sim 28 \%)$ are located in Istomino village as several days of observations were recorded there between 29 June and 7 July 2013. In order not to give the Baikal region an excessive weight, the LR distribution is computed on the 76 profiles recorded elsewhere than Istomino village (Fig. 2). LR values during the campaign range from 32 to $106 \mathrm{sr}$, with an average and standard deviation of $63 \pm 17 \mathrm{sr}$; the distribution is slightly skewed towards high values (median LR is $61 \mathrm{sr}$ and first/last quartiles are 51/74 sr). In Istomino village, the distribution (not shown) exhibits higher and more scattered values (average/standard deviation of $70 \pm 20 \mathrm{sr}$ ) associated 


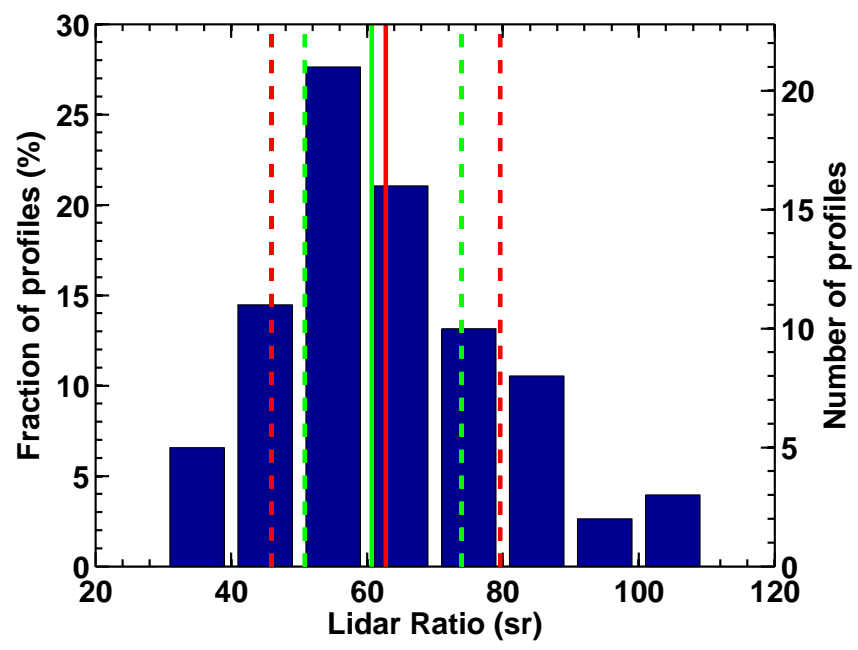

Figure 2. Distribution of the lidar ratio (LR) values obtained by constraining Klett's inversion with the partial aerosol optical thickness provided by the $\mathrm{N}_{2}$-Raman channel between 0.3 and $0.7 \mathrm{~km}$ above ground level. The only profiles included are the $7630 \mathrm{~min}$ average profiles for which the agreement was better than $10^{-3}$ (and this for all the 200 profiles generated by the Monte Carlo algorithm). Profiles from Istomino village (Lake Baikal shore) have also been removed. The red (resp. green) lines represent the $L R$ average value and $1 \sigma$ standard deviation (resp. the median and quartiles).

with a generally low aerosol load observed near Lake Baikal (the average AOT was only 0.07 at $355 \mathrm{~nm}$ ).

A sample of the LR observations available in the literature for different types of aerosols is presented in Table 1 (desert dust), Table 2 (biomass burning) and Table 3 (anthropogenic pollution). This shows that the LR distribution observed during the Paris-Baikal journey is compatible with previous observations for pollution aerosols, aged smoke and mixes with terrigenous particles (dust), which are the types of aerosol that can be expected in such continental conditions.

In the following parts of Sect. 3 , the 30 min average profiles are processed using Klett's inversion with a constant LR of $58 \mathrm{sr}$ when considering the entire atmospheric column. For specific study in the PBL, between 300 and $700 \mathrm{~m}$, the $\mathrm{N}_{2}$ Raman Channel was used to assess LR.

\subsection{Classification of aerosols along the route}

In order to discuss the distribution of aerosols along the transect, Fig. 3 presents the AOT and PDR inverted from all the $30 \mathrm{~min}$ average profiles, plotted against longitude. Profiles recorded within a radius of $15 \mathrm{~km}$ are grouped and replaced by their average, which leaves 122 profiles. To discuss the vertical distribution of aerosols, the partial AOT and the average PDR below and above a fixed level are computed. An altitude of $1500 \mathrm{~m}$ a.g.l. was chosen as it can be considered as an average value for continental PBL or residual layer top, i.e. the maximum altitude influenced by the ground. Values of PDR above $1500 \mathrm{~m}$ a.g.l. are scarce because this ratio cannot be computed for profiles gathered around noon (the depolarization channel SNR is too low) or when the aerosol load is too small in the free troposphere.

To obtain more insight into the type of aerosols encountered during the route, the scatter plot of PDR vs LR values in the PBL (300-700 m a.g.1.) is presented in Fig. 4. The uncertainty on the LR values is the standard deviation of the LR distribution provided by the Monte Carlo algorithm. The uncertainty on the PDR value is computed following the process described in Appendix B. Dots are coloured according to their geographic origin. In Russia, profiles were split between urban and background cases, the "urban" criterion being a longitude difference smaller than $0.5^{\circ}$ with the city centre. Profiles were also split between the dust event zone (longitude from 45 to $75^{\circ} \mathrm{E}$ ) and the rest of the country. Cities in the dust zone are Kazan, Ufa, Chelyabinsk and Omsk (Ishim is not included because too small); other Russian cities are Pskov, Moscow, Nizhniy-Novgorod, Novosibirsk, Irkutsk and Ulan-Ude (Nizhneudinsk is not included because too small). Krasnoyarsk was analysed separately.

European part of the route. Aerosols from Europe (longitude $<26^{\circ}$ E, red dots in Fig. 4) are characterized by rather high LR and low PDR values (60-102 sr and $<1 \%$ ) indicating the predominance of spherical carbonaceous particles (pollution aerosols). This is the case for large cities such as Paris and Berlin. PDR values in the rural regions of Central Germany are slightly higher $(<2 \%)$. Over Germany and Poland (particularly near Frankfurt, Berlin and Warsaw), higher values of free tropospheric AOT show the presence of elevated aerosols layers with PDR values similar to those found in the PBL, suggesting that this is probably pollution lifted up and transported from another part of Europe.

Russian part of the route. In Russian cities (black and orange dots in Fig. 4), the urban PBL is generally characterized by slightly higher PDR values $(2-4 \%)$ as compared to Europe, which indicates that the particle composition results from a mixture of traffic and industrial emissions with terrigenous aerosols. Russian cities east of Moscow appear much dustier than European cities due to bad road tarmac and lack of vegetation on traffic islands, which results in a lot of terrigenous aerosols being lifted up by the wind and by road traffic and injected in the urban PBL. The large dispersion of LR values may be due to a strong variability of aerosol types. Krasnoyarsk is the only one city where PDR values are comparable with European cities (yellow dots in Fig. 4) but this is probably not due to a difference in the aerosol sources. Indeed, heavy rain had fallen during the night before the van went through the city and the ground was still wet, proving that the terrigenous aerosol had all been washed down. Between Krasnoyarsk and Nizhneudinsk, AOT values up to 0.28 have been observed (Fig. 3), with a large fraction located in the free troposphere (up to $47 \%$ ). As they are associated with very low values of PDR $(<1 \%)$, both below and above $1500 \mathrm{~m}$ a.g.l., it could either be pollution aerosols 


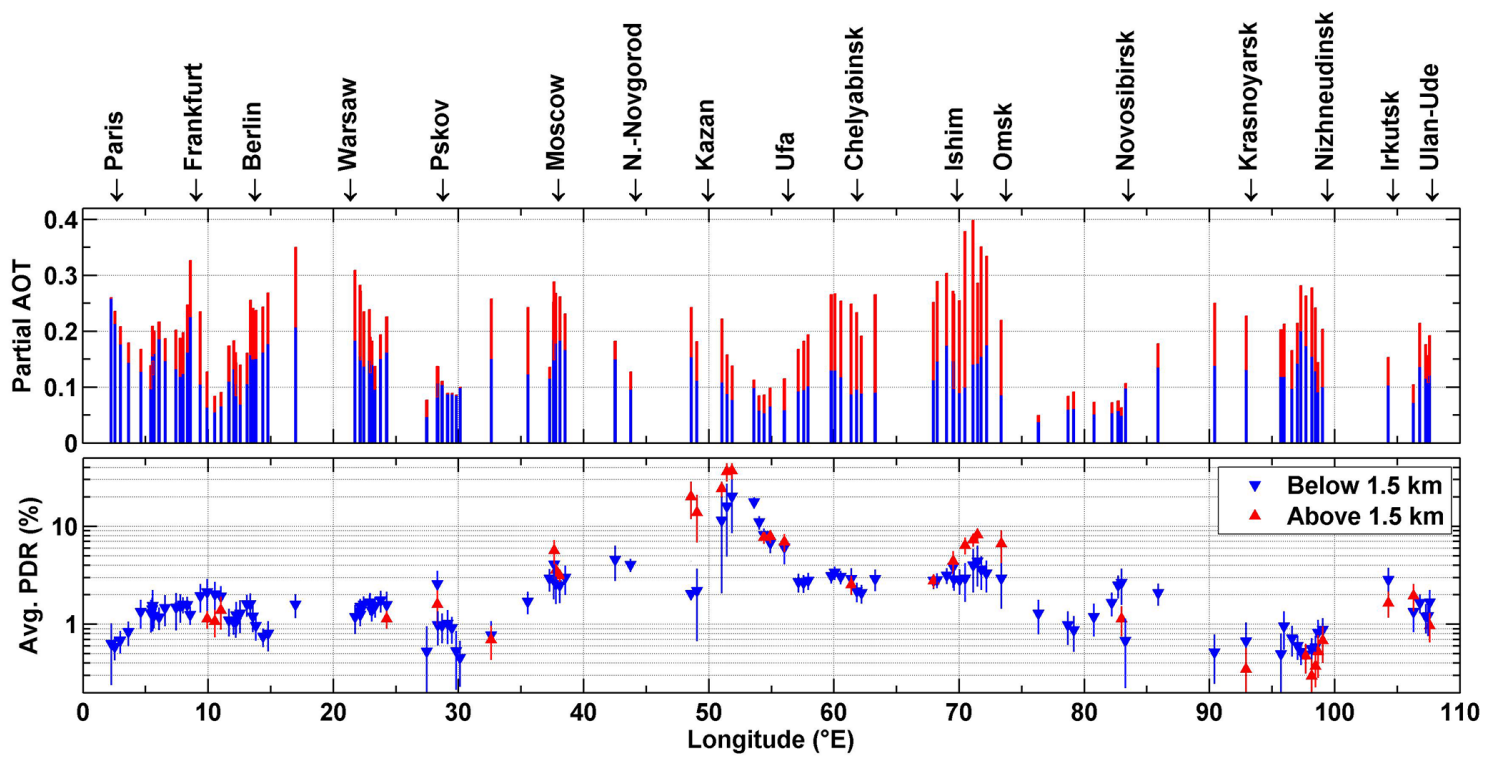

Figure 3. Partial aerosol optical thickness (AOT, top) and average particle depolarization ratio (PDR, bottom) along the route, computed below (in blue) and above (in red) $1500 \mathrm{~m}$ a.g.l. All values are inverted from the $30 \mathrm{~min}$ average profiles using Klett's inversion with a fixed lidar ratio of $58 \mathrm{sr}$. The average PDR is computed only when the scattering ratio is greater than 1.05 .

Table 1. Values of the extinction-to-backscatter ratio (also called lidar ratio or LR) and particle depolarization ratio (PDR) reported in the literature and observed in this study for desert dust aerosols, pure or mixed with biomass burning or pollution. For Burton et al. (2012), values are the 25-75th (5-95th) percentiles, respectively.

\begin{tabular}{|c|c|c|c|c|c|c|}
\hline $\begin{array}{l}\text { Aerosol } \\
\text { type }\end{array}$ & Site, campaign & $\begin{array}{l}\text { Instrument, } \\
\text { inversion method }\end{array}$ & $\lambda(\mathrm{nm})$ & $\begin{array}{l}\text { LR } \\
(\mathrm{sr})\end{array}$ & $\begin{array}{l}\text { PDR } \\
(\%)\end{array}$ & Reference \\
\hline \multirow[t]{10}{*}{ Pure dust } & AERONET network & AERONET Sun photometer & 550 & $42 \pm 4$ & - & Cattrall et al. (2005) \\
\hline & $\begin{array}{l}\text { North America, } \\
\text { multi campaign }\end{array}$ & $\begin{array}{l}\text { High spectral } \\
\text { resolution lidar (HSRL) }\end{array}$ & 532 & $\begin{array}{c}44-51 \\
(41-57)\end{array}$ & $\begin{array}{c}31-33 \\
(30-35)\end{array}$ & Burton et al. (2012) \\
\hline & $\begin{array}{l}\text { Morocco and Cabo Verde, } \\
\text { SAMUM }\end{array}$ & $\mathrm{N}_{2}$ Raman lidar & 355 & $58 \pm 7$ & $25 \pm 3$ & $\begin{array}{l}\text { Groß et al. (2011) } \\
\text { Müller et al. (2012) }\end{array}$ \\
\hline & $\begin{array}{l}\text { Thessaloniki (Greece) } \\
\text { (western Saharan dust) }\end{array}$ & $\mathrm{N}_{2}$ Raman lidar & 355 & $57 \pm 29$ & - & Amiridis et al. (2005) \\
\hline & $\begin{array}{l}\text { Maldives Islands, INODEX } \\
\text { (Saudi Arabian dust) }\end{array}$ & $\mathrm{N}_{2}$ Raman lidar & 355 & $38 \pm 5$ & - & Müller et al. (2007) \\
\hline & $\begin{array}{l}\text { Beijing (China) } \\
\text { (Gobi desert dust) }\end{array}$ & $\mathrm{N}_{2}$ Raman lidar & 532 & $35 \pm 5$ & - & Müller et al. (2007) \\
\hline & Tokyo (Japan) & $\mathrm{N}_{2}$ Raman lidar & 355 & $49 \pm 9$ & $\sim 20$ & Murayama et al. (2004) \\
\hline & Niamey (Niger) & $\mathrm{N}_{2}$ Raman lidar & 355 & $\sim 50$ & - & Chazette et al. (2007) \\
\hline & $\begin{array}{l}\text { Sahel, Middle East, India } \\
\text { synergy }\end{array}$ & CALIOP / AERONET & 532 & $50,39,44$ & - & Schuster et al. (2012) \\
\hline & Cyprus (Syrian dust) & $\mathrm{N}_{2}$ Raman lidar & 532 & $34-39$ & $28-35$ & Mamouri et al. (2013) \\
\hline \multirow[t]{4}{*}{ Dusty mix } & $\begin{array}{l}\text { North America, } \\
\text { multi campaign }\end{array}$ & HHSRL & 532 & $\begin{array}{c}30-42 \\
(15-63)\end{array}$ & $\begin{array}{c}13-20 \\
(10-28)\end{array}$ & Burton et al. (2012) \\
\hline & Mor./C. Verde, SAMUM & $\mathrm{N}_{2}$ Raman lidar & 355 & $75 \pm 9$ & $18 \pm 3$ & $\begin{array}{l}\text { Groß et al. (2011) } \\
\text { Müller et al. (2012) }\end{array}$ \\
\hline & Niamey (Niger) & $\mathrm{N}_{2}$ Raman lidar & 355 & $\sim 67$ & - & Chazette et al. (2007) \\
\hline & Balearic islands, HyMeX & $\mathrm{N}_{2}$ Raman lidar & 355 & $47-63$ & $16-19$ & Chazette et al. (2014) \\
\hline \multirow[t]{2}{*}{ Pure dust } & Kazan, lower sub-layer & Multi-layer Raman constr. & 355 & $43 \pm 14$ & $23 \pm 2$ & This study \\
\hline & Kazan, upper sub-layer & Multi-layer Raman constr. & & $22 \pm 12$ & $20 \pm 2$ & \\
\hline Dusty mix & azan, upper sub-layer & & & $75 \pm 9$ & $13 \pm 3$ & \\
\hline Pure dust & Omsk & Full Raman inversion & & $50 \pm 13$ & $17 \pm 2$ & \\
\hline
\end{tabular}


Table 2. As Table 1, but for biomass burning aerosols, either freshly emitted or aged. When the extinction-to-backscatter ratio (LR) and the particle depolarization ratio (PDR) have been retrieved at different wavelengths, the two values of wavelength are given.

\begin{tabular}{|c|c|c|c|c|c|c|}
\hline Aerosol type & Site, campaign & $\begin{array}{l}\text { Instrument, } \\
\text { inversion method }\end{array}$ & $\lambda(\mathrm{nm})$ & $\begin{array}{l}\mathrm{LR} \\
(\mathrm{sr})\end{array}$ & $\begin{array}{l}\text { PDR } \\
(\%)\end{array}$ & Reference \\
\hline \multirow[t]{2}{*}{ Fresh smoke } & $\begin{array}{l}\text { North America, } \\
\text { multi campaign }\end{array}$ & $\begin{array}{l}\text { High spectral } \\
\text { resolution lidar }\end{array}$ & 532 & $\begin{array}{c}34-46 \\
(24-54)\end{array}$ & $\begin{array}{c}3-5 \\
(2-8)\end{array}$ & Burton et al. (2012) \\
\hline & Bucharest, EARLINET & $\mathrm{N}_{2}$ Raman lidar & 355 & $73 \pm 12$ & - & Nicolae et al. (2013) \\
\hline \multirow[t]{7}{*}{ Aged smoke } & AERONET network & Sun-photometer & 550 & $60 \pm 8$ & - & Cattrall et al. (2005) \\
\hline & $\begin{array}{l}\text { North America, } \\
\text { multi campaign }\end{array}$ & $\begin{array}{l}\text { High spectral } \\
\text { resolution lidar }\end{array}$ & 532 & $\begin{array}{c}55-72 \\
(46-86)\end{array}$ & $\begin{array}{c}4-9 \\
(2-15)\end{array}$ & Burton et al. (2012) \\
\hline & Tokyo (Siberian smoke) & $\mathrm{N}_{2}$ Raman lidar & 355 & $\sim 40$ & $5-8$ & Murayama et al. (2004) \\
\hline & Leipzig, EARLINET & $\mathrm{N}_{2}$ Raman lidar & 355-532 & $46 \pm 13$ & $<5$ & Müller et al. (2005) \\
\hline & $\begin{array}{l}\text { Thessaloniki (Greece) } \\
\text { (from Russia, Ukraine ) }\end{array}$ & $\mathrm{N}_{2}$ Raman lidar & 355 & $39-94$ & - & Amiridis et al. (2009) \\
\hline & $\begin{array}{l}\text { Morocco/Cabo Verde, } \\
\text { SAMUM }\end{array}$ & $\mathrm{N}_{2}$ Raman lidar & 355-532 & $87 \pm 17$ & $5 \pm 2$ & Tesche et al. (2011) \\
\hline & Bucharest, EARLINET & $\mathrm{N}_{2}$ Raman lidar & 355 & $32-48$ & - & Nicolae et al. (2013) \\
\hline \multirow[t]{4}{*}{ Aged smoke } & Kazan & Multi-layer Raman constr. & 355 & $107 \pm 14$ & $4 \pm 2$ & This study \\
\hline & Ishim & Full Raman inversion & & $65 \pm 6$ & $3 \pm 1$ & \\
\hline & Omsk & Full Raman inversion & & $76 \pm 10$ & $4 \pm 2$ & \\
\hline & Nizhneudinsk & Full Raman inversion & & $63 \pm 15$ & $\sim 1$ & \\
\hline
\end{tabular}

Table 3. As Tables 1 and 2, but for pollution aerosols.

\begin{tabular}{|c|c|c|c|c|c|}
\hline Site, campaign & $\begin{array}{l}\text { Instrument, } \\
\text { inversion method }\end{array}$ & $\lambda(\mathrm{nm})$ & $\begin{array}{l}\mathrm{LR} \\
(\mathrm{sr})\end{array}$ & $\begin{array}{l}\text { PDR } \\
(\%)\end{array}$ & Reference \\
\hline AERONET network & Sun-photometer & 550 & $71 \pm 10$ & - & Cattrall et al. (2005) \\
\hline $\begin{array}{l}\text { North America, } \\
\text { multi campaign }\end{array}$ & $\begin{array}{l}\text { High spectral } \\
\text { resolution lidar }\end{array}$ & 532 & $\begin{array}{c}52-69 \\
(42-80)\end{array}$ & $\begin{array}{c}3-8 \\
(2-11)\end{array}$ & Burton et al. (2012) \\
\hline Central Europe, EARLINET & $\mathrm{N}_{2}$ Raman lidar & 355-532 & $58 \pm 12$ & $<5$ & $\begin{array}{l}\text { Mattis et al. (2004) } \\
\text { Müller et al. (2007) }\end{array}$ \\
\hline Paris, ESQUIF & Lidar/sun-phot. synergy & 532 & $59-77$ & - & Chazette et al. (2005) \\
\hline Paris, LISAIR & $\mathrm{N}_{2}$ Raman lidar & 355 & $83 \pm 22$ & - & Raut and Chazette (2007) \\
\hline Paris & $\mathrm{N}_{2}$ Raman lidar & 355 & $85 \pm 18$ & - & Royer et al. (2011) \\
\hline Po Valley & CALIOP/MODIS synergy & 532 & $83 \pm 25$ & - & Royer et al. (2010) \\
\hline North India (INDOEX) & $\mathrm{N}_{2}$ Raman lidar & 532 & $65 \pm 16$ & - & Franke et al. (2001) \\
\hline South India & & & $37 \pm 10$ & & Franke et al. (2003) \\
\hline South-East Asia & & & $51 \pm 20$ & & \\
\hline Pearl River delta (China) & $\mathrm{N}_{2}$ Raman lidar & 532 & $47 \pm 6$ & - & Ansmann et al. (2005) \\
\hline Beijing (China) & $\mathrm{N}_{2}$ Raman lidar & 532 & $38 \pm 7$ & - & Tesche et al. (2007) \\
\hline $\begin{array}{l}\text { Omsk (residual layer, } \\
\text { after sunset/middle of night) }\end{array}$ & Full Raman inversion & 355 & $\begin{array}{l}67 \pm 12 \\
92 \pm 18\end{array}$ & $\begin{array}{l}4 \pm 1 \\
3 \pm 1\end{array}$ & This study \\
\hline
\end{tabular}

transported from the industrial city of Krasnoyarsk, or more probably part of a forest fire plume.

Desert dust in Russia. The values of PDR $>10 \%$ (Fig. 3) between Kazan and Ufa $\left(\sim 52^{\circ} \mathrm{E}\right)$ correspond to a desert dust event, with first, an elevated layer (PDR 35\%) and then, mixing of the dust into the PBL (PDR $\sim 17 \%$ ). The highest AOT values (up to 0.40 , associated with up to $70 \%$ of the AOT above $1500 \mathrm{~m}$ a.g.l.) were observed farther east, between Ishim and Omsk $\left(\sim 71^{\circ} \mathrm{E}\right)$. However, the PDR values
(5-9\%) indicate that a mixing has occurred with combustion aerosols, most probably of biomass burning origin since the region is very isolated. Indeed, combustion aerosols from pollution or biomass burning are found with PDR values below $5 \%$ at $355 \mathrm{~nm}$ while aerosol mixes dominated by dustlike particles usually have PDR values above $10 \%$ and pure desert dust above $20 \%$ (see references in Tables 1, 2 and 3).

The PDR values of $\sim 35 \%$ found between Kazan and Ufa (Fig. 3, lower panel) are very high for dust but they were de- 


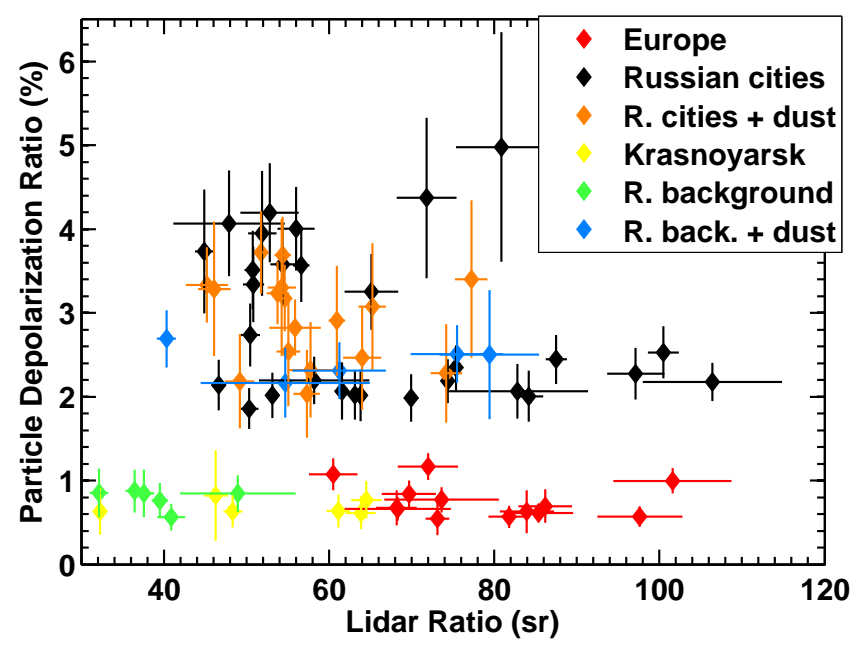

Figure 4. Scatter plot of the particle depolarization ratio (PDR) vs. lidar ratio (LR) values retrieved in the constraint zone $(300-700 \mathrm{~m}$ averages) for the 76 convergent $30 \mathrm{~min}$ average profiles from Fig. 2. Profiles are sorted into six types of atmospheric and geographic conditions.

rived using the campaign average $\mathrm{LR}$ in the $\mathrm{PBL}$, not with a dust-optimized LR value, which results in large uncertainties. Besides, values of $38 \%$ have already been observed at $355 \mathrm{~nm}$ in volcanic ash plumes (Ansmann et al., 2011). Russian cities located in the area where elevated layers of dust were observed (orange dots in Fig. 4) do not show a different distribution of LR and PDR compared to other Russian cities (black dots). This indicates that the mixing of the elevated dust layers towards the PBL was low, or that its effects were limited as the LR values were already affected by terrigenous aerosols from local sources lifted in the PBL.

Background aerosols. In unpopulated areas of Russia, aerosols are probably a mix between aged particles from biomass burning and secondary organic aerosols, so that very low depolarization can be expected when no dust is present (PDR $<1 \%$ ). Also, under local terrigenous aerosol sourcefree conditions, the dust plume has a more sensible effect on the PDR than in town. LR values in remote areas are rather low (32-50 sr). However, in the absence of dust, the AOT values used as constraint are small and result in large uncertainties on the LR values. Note that the smallest AOT values (below 0.1 at $355 \mathrm{~nm}$, Fig. 3) were derived between Pskov and Smolensk (west of Moscow) and in Siberia between Omsk and Novosibirsk, and close to Istomino village, on the shore of Lake Baikal (between Irkutsk and Ulan-Ude). They correspond to periods interspersed with rain.

\subsection{Temporal representativeness of the observations}

The lidar-derived AOT values presented in Sect. 3.1 were compared with the AOT measured by MODIS Terra. A multiyear average was computed from the monthly $1^{\circ} \times 1^{\circ}$ gridded product (MOD08_M3) using the months of June from years
2000 to 2013 (years 2001, 2003 and 2012 were removed because, due to intense fire events, those years are too far from the conditions encountered during the campaign). MODIS data from the grid pixel where the lidar was located were extracted without any spatial interpolation. For the four AERONET stations located close to the transect (Palaiseau, Mainz, Moscow and Irkutsk), monthly averages were computed from the daily averages including at least four observations, then the multi-year June average was computed from years 2006 to 2013 (the time period is shorter than for MODIS because Mainz and Irkutsk records started in 2006). The AOT values were all converted to $355 \mathrm{~nm}$ using the Angström coefficients provided by MODIS and AERONET. The resulting AOT values for the lidar, MODIS and AERONET are presented in Fig. 5 (top panel).

The lidar-derived AOT stays within a $1 \sigma$ interval around the MODIS multi-annual June average during most of the journey. The largest deviation from MODIS average was observed between Ishim and Omsk, due to the mixed dust and biomass burning event identified in Sect. 3.2. The pure dust layers observed near Kazan, as well as the fire or pollution layers observed near Nizhneudinsk, are associated with moderate AOT values, which remain close to the MODIS average. However, the MODIS daily $1^{\circ} \times 1^{\circ}$ product (not shown) displays AOT values larger than the lidar observations (up to 0.6), suggesting that we did not sample the heart of the plumes. Elsewhere, AOT values standing clearly below MODIS highlight the areas where we observed background aerosols, i.e. between Pskov and Smolensk $\left(\sim 30^{\circ} \mathrm{E}\right.$, west of Moscow), between Omsk and Novosibirsk $\left(\sim 80^{\circ} \mathrm{E}\right)$ and in central Germany (Leipzig area). This AOT comparison shows that our observations are representative of the aerosol load existing above Europe and Russia in June, in the absence of exceptional fire or dust events.

In the middle and bottom panels of Fig. 5, the blue curves (green dots) represent respectively the 470-660 (440-675) $\mathrm{nm}$ Angström coefficient and the 550 (500) nm AOT finemode fraction from MODIS Terra (AERONET). The average and standard deviation have been computed the same way as the AOT. The drop in MODIS AOT around $23^{\circ} \mathrm{E}$ (Poland-Lithuania border) is correlated with an increase of the Angström coefficient and of the fine-mode fraction, indicating that the aerosol mix in Russia contains more small particles than in Europe, which is in apparent contradiction with the observations of our lidar highlighting the presence of a larger fraction of coarse terrigenous particles over Russia.

However, this discrepancy probably results from the differences in the observation scales. The LR and PDR values observed by the lidar indicate the presence of coarse terrigenous aerosols in the lower PBL (300-700 m a.g.1.) and nearby the road followed by the van, which is one of the busiest of Russia with heavy truck traffic. On the other hand, MODIS represents an average over the whole atmospheric column and a large land surface $\left(111 \times 64 \mathrm{~km}^{2}\right.$ at $\left.55^{\circ} \mathrm{N}\right)$ so it 


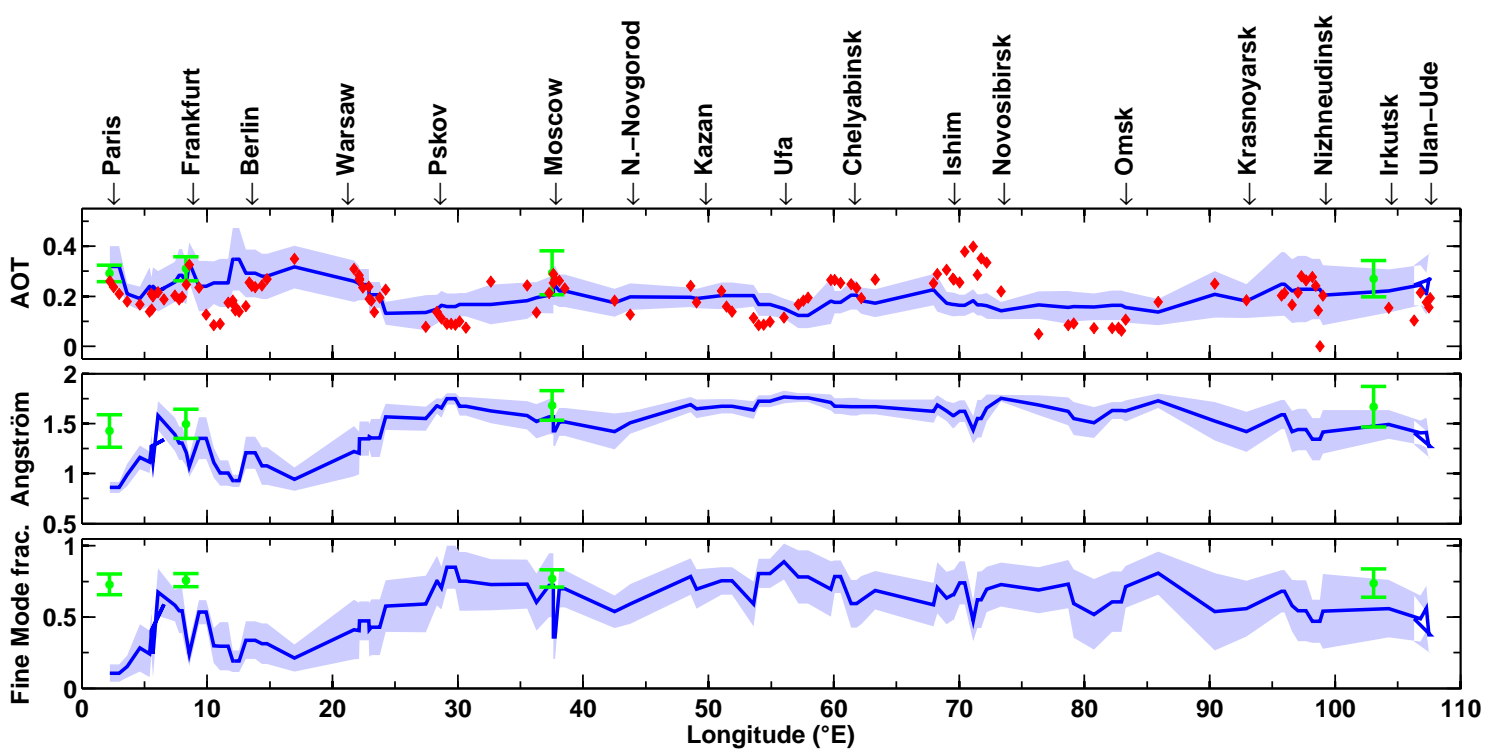

Figure 5. Top: aerosol optical thickness (AOT) at $355 \mathrm{~nm}$ from the lidar (red), from MODIS Terra (blue) and from the AERONET stations along the transect (green). Middle: Ångström coefficients from MODIS Terra (470-660 nm) and from AERONET (440-675 nm). Bottom: AOT small-mode fraction from MODIS Terra $(550 \mathrm{~nm})$ and from AERONET $(500 \mathrm{~nm})$. For MODIS (MOD08_M3 product), the $1^{\circ} \times 1^{\circ}$ pixels including the van position were extracted and the months of June from years 2000 to 2013 (except years 2001,2003 and 2012 due to intense fire events) were used to compute MODIS average and standard deviation (blue line and shading). For AERONET, only data since 2006 were used since only Palaiseau $\left(2.5^{\circ} \mathrm{E}\right)$ has data prior to this year.

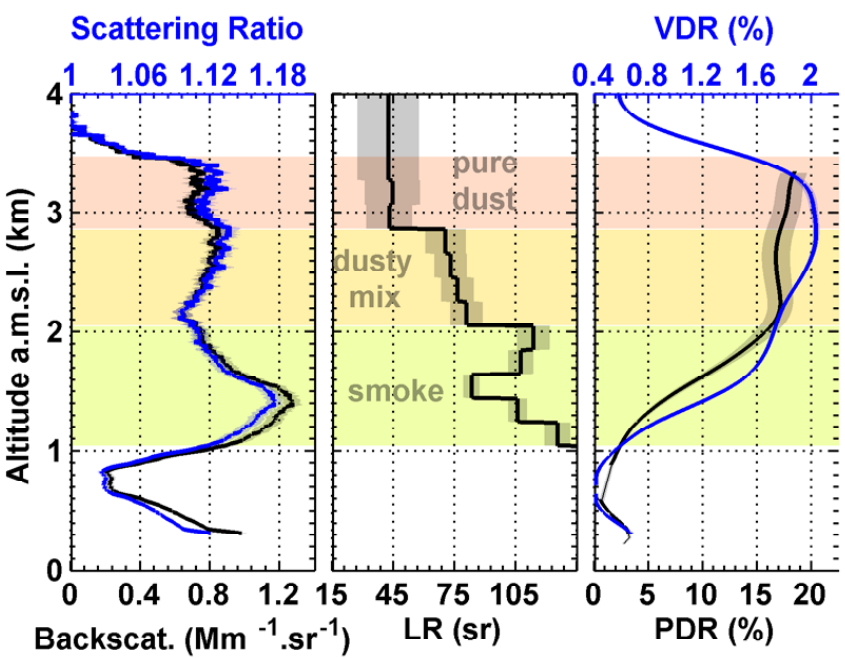

Figure 6. Vertical profiles of aerosol backscatter and lidar ratio (LR) determined from the 55 min average profile on 18 June 2013, using either the low-pass derivative filter inversion (blue) or the constrained Klett procedure on a sliding $200 \mathrm{~m}$ window (red). Shaded areas represent the uncertainties from the Monte Carlo process. For these mobile observations, the altitude is above mean sea level (a.m.s.l.); the ground average altitude was around $0.1 \mathrm{~km}$ a.m.s.l.

is more representative of the free troposphere and of the rural areas of Russia, where the aerosol mixture is dominated by biomass burning particles. Only in Moscow, where the city is large enough to occupy a significant part of the $1^{\circ} \times 1^{\circ}$ pixel, does MODIS exhibit a drop of the fine-mode fraction down to European values. Those changes in the Ångström coefficient and in the fine-mode fraction are not visible on the sun-photometers data, maybe due to a difference between the aerosol models used in AERONET and MODIS retrievals.

\section{Characterization of dust and biomass burning aerosols events}

This section presents case studies of dust or biomass burning aerosol plumes during which a finer characterization of the optical properties of these particles was possible through the retrieval of their lidar ratio using a Raman or multi-layer constrained Klett inversion. The origin of the particles is also studied for each aerosol plume. Finally, we discuss our results taking into account the observations made in other regions of the world.

\subsection{Case studies}

\subsubsection{Dust and biomass burning aerosols observed west of Kazan}

The first significant observation of dust layers occurred near Kazan $\left(49^{\circ} \mathrm{E}, 56^{\circ} \mathrm{N}\right)$ on 18 June 2013. The LR and PDR profiles are computed on a $55 \mathrm{~min}$ average profile recorded just after sunset. Figure 6 presents the results from the Raman inversion and from the multi-layer constrained Klett inversion, along with the uncertainties computed through the 
Monte Carlo process. The two inversions result in a very good agreement above $1.05 \mathrm{~km}$ a.m.s.l.; below this altitude, the constrained Klett procedure did not converge due to the low aerosol load, meaning that the high LR values provided in this layer by the Raman inversion are not significant either. The uncertainties on the lidar ratio profiles are relatively large and come from the low signal-to-noise ratio $(\sim 20)$ due to an averaging time limited by cloud cover.

According to the PDR profile (Fig. 6, right), the dust layer extends from 2.05 to $3.45 \mathrm{~km}$ a.m.s.l (average PDR of $19 \pm 2 \%$ ). Compared to the references summarized in Table 1, the lidar ratios retrieved in the upper part of the layer (2.85-3.45 kma.m.s.l.) are typical of pure dust: $48 \pm 16 \mathrm{sr}(43 \pm 14 \mathrm{sr})$ for the Raman inversion (resp. constrained Klett inversion). In the lower part of the layer (2.05-2.85 km a.m.s.l.), the lidar ratio values are $78 \pm 12 \mathrm{sr}$ ( $75 \pm 9$ sr) for the Raman inversion (resp. constrained Klett inversion), which suggests a mix between dust and biomass burning aerosols within the atmospheric column. Indeed, below the dust layer, the PDR drops down to values $<10 \%$ that are typical for smoke (see references in Table 2). The lidar ratios in this layer also point toward combustion particles, though the values are higher than what is reported in the literature, with $107 \pm 14 \mathrm{sr}$ for both inversion methods (1.05$2.05 \mathrm{~km}$ a.m.s.l. average).

The temporal evolution of this event is studied using $5 \mathrm{~min}$ average profiles. The inversion is performed using the LR profile derived from the constrained Klett procedure. The resulting AOT, aerosol backscatter coefficient and PDR are presented in Fig. 7. The AOT is slightly lower than the values provided by MODIS Aqua $(\sim 0.5)$, but the satellite overpass took place at 09:20 UTC, i.e. 8 to $9 \mathrm{~h}$ before the lidar observations. Moreover, the map of MODIS AOT (not shown) indicates that we sampled the eastern edge of the plume, which is confirmed by the decreasing AOT values observed as the van moves eastwards.

The backscatter and PDR time-height cross-sections show that the dust layer became thinner from 17:30 UTC and moved upwards (Fig. 7, middle and bottom panels). As the profile used for LR retrieval is an average between 17:29 and 18:24 UTC, this explains why the LR values below $2.85 \mathrm{~km}$ a.m.s.l. correspond to a dust-smoke mix. In contrast, the time-height cross-sections show that dust remains present above $2.85 \mathrm{~km}$ a.m.s.l. and confirm that the LR of $43 \pm 14 \mathrm{sr}$ retrieved in this layer can be attributed to pure dust. The PDR reaches values of $\sim 23 \pm 2 \%$ in the heart of the layer (average from 17:15 to 17:45 UTC and between 2.05 and $2.85 \mathrm{~km}$ a.m.s.1.), which is close to other observations at $355 \mathrm{~nm}$ for pure dust (Table 1; Groß et al., 2011; Müller et al., 2012). In the biomass burning layer (1.05$1.4 \mathrm{~km}$ a.m.s.l.), the PDR is $\sim 4 \pm 2 \%$ on average while it is $\sim 13 \pm 3 \%$ in the dust-smoke mix (after 18 UTC, 2$2.8 \mathrm{~km}$ a.m.s.l.).

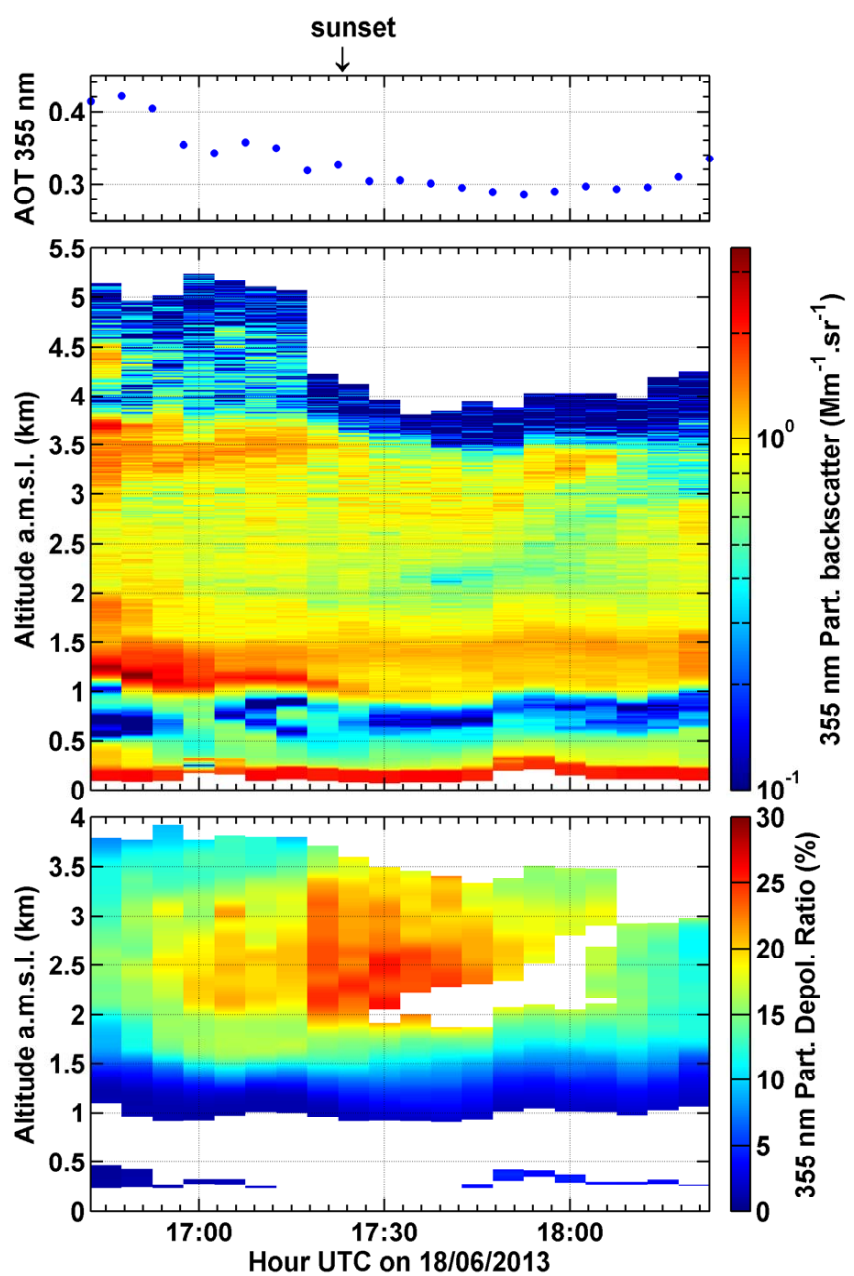

Figure 7. Aerosol optical thickness (AOT, top), backscatter (middle) and particle depolarization ratio (PDR, bottom) observed west of Kazan on 18 June 2013 twilight as a function of UTC time and altitude above mean sea level (a.m.s.l.). Retrieval was made using a Klett inversion with the backscatter to extinction ratio profile from the sliding-window constrained Klett procedure (Fig. 6, middle panel).

\subsubsection{Dust and biomass burning aerosols observed above Omsk}

Omsk is one of Russia's largest industrial centres and a 1.15 million inhabitant city located $2300 \mathrm{~km}$ East of Moscow $\left(55^{\circ} \mathrm{N}, 73^{\circ} \mathrm{E}\right)$. Several oil and gas fields are exploited north of the city, whose industry is dominated by hydrocarbon production. The van was stationed in the centre of the city, near the Irtysh River, during the night of 22-23 June.

Observations show the successive overpass of a dust layer and a biomass burning layer over the van. To retrieve the lidar ratio, two average profiles were computed: one that samples the dust layer (16:44-19:12 UTC) and one during the overpass of the biomass burning layer (19:12-21:42 UTC). Figure 8 presents the LR profiles computed using the Raman 

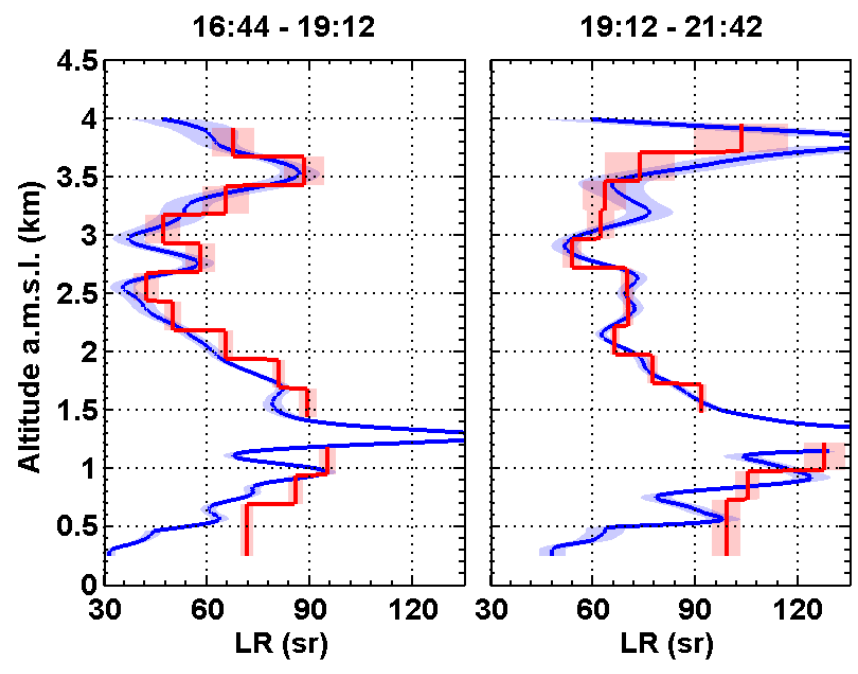

Figure 8. Profiles of lidar ratio (LR) retrieved above Omsk city on 22 June 2013 from two different processes: (red) profiles from the sliding-window constrained Klett process, (blue) profiles from the low-pass derivative filter inversion (Raman inversion). Shaded areas represent the uncertainties from the Monte Carlo process.

inversion and the multi-layer constrained Klett inversion. In the heart of the dust layer (left profile, $2.5-3.5 \mathrm{~km}$ a.g.l.), the average LR is $50 \pm 11 \mathrm{sr}(54 \pm 11 \mathrm{sr})$ according to the Raman inversion (resp. constrained Klett inversion), which is close to the layer observed near Kazan and typical of pure desert dust aerosol (references in Table 1). In the biomass burning layer (right profile, $1.5-2.5 \mathrm{~km}$ a.g.l.), both inversion methods lead to an average LR of $76 \pm 10 \mathrm{sr}$, a value that is compatible with the literature (references in Table 2).

In the residual layer (0.5-1.0 km a.g.l.), LR values increase during the night: for the Raman inversion, the average LR before 19UTC (profile \#1) is $67 \pm 12 \mathrm{sr}$ while it reaches $92 \pm 18 \mathrm{sr}$ after $19 \mathrm{UTC}$ (profile \#2). The values provided by the constrained Klett inversion are higher $(79 \pm 8 \mathrm{sr}$, then $101 \pm 4 \mathrm{sr}$ ) and show less agreement with the literature (references in Table 3), the highest reported values being $\sim 83 \mathrm{sr}$ (Raut and Chazette, 2007; Royer et al., 2010, 2011). This increase in LR is possibly due to a change in the aerosol mix during the night: as the large terrigenous particles lifted from the road tarmac during the day return progressively to the ground, highly absorbing pollution aerosols become dominant. Such an effect was also observed in Irkutsk (not shown).

The LR profiles retrieved from the constrained Klett inversion are used to invert the $5 \mathrm{~min}$ average profiles; the resulting AOT, backscatter coefficient and PDR are presented in Fig. 9. The decrease of AOT from 15 to 19 UTC stems mainly from the decrease of the particle extinction (and backscatter) in the residual layer after sunset, following the disconnection from fresh ground emissions. It goes along with a slight decrease of the average PDR below $1.2 \mathrm{~km}$ a.g.l. (from $4 \pm 1 \%$ before sunset to $3 \pm 1 \%$ after $18 \mathrm{UTC}$ ) also supporting the terrigenous fallout hypothesis. Those depolarization values are coherent with the classification of Burton et al. (2012), who reported $532 \mathrm{~nm}$ PDR values from 3 to $8 \%$ for pollution aerosols, and with the observations of Müller et al. (2007), who always observed PDR values lower than $5 \%$ for urban haze.

The backscatter and PDR time-height cross-sections show the existence of a second, thinner smoke plume moving upward just above the dust plume, which could explain why the average PDR is only $17 \pm 2 \%$ is the dust plume (16:45-19:00 UTC and 2.5-3 km a.g.l.). In the biomass burning plume, the average PDR is $4 \pm 2 \%$ (after 19:30 UTC and 1.6-2.6 km a.g.l.) with a zone where it drops to $2 \pm 1 \%$ (19:45-21:00 UTC and 1.5-2 km a.g.l.). The clean layer isolating the smoke plume from the residual layer is associated with a sharp wind shear visible on the reanalyses from the European Centre for Medium-range Weather Forecast (not shown). MODIS observations show that, again, the lidar sampled only the edge of the plume as the $355 \mathrm{~nm}$ AOT reached $\sim 0.7$ on 22 June morning (Terra/Aqua, $\sim$ 07:00 UTC) but only $\sim 0.2$ remained on 23 June morning (Terra, 06:10 UTC), a value in agreement with the lidar AOT measured $5 \mathrm{~h}$ earlier.

\subsubsection{Additional cases}

Two additional cases that cannot be detailed extensively are briefly described in this section; results are summarized in Tables 1 and 2. One day before the Omsk case study (night from 21-22 June), similar observations were recorded near the town of Ishim $\left(65000\right.$ inhabitants, $\left.56^{\circ} \mathrm{N}, 69^{\circ} \mathrm{E}\right)$, with a dust layer after sunset (though too thin to properly determine an average LR and PDR) and a biomass burning layer during the second part of the night (LR of $65 \pm 6 \mathrm{sr}$, PDR of $3 \pm 1 \%)$. Then, during the night from $25-26$, the van halted in the small city of Nizhneudinsk $\left(55^{\circ} \mathrm{N}, 99^{\circ} \mathrm{E}, 37000\right.$ inhabitants). No dense layers of aerosols were visible but a diffuse background reached up to $3.5 \mathrm{~km}$ a.g.l., with an average LR of $63 \pm 15 \mathrm{sr}$ and an average PDR $\sim 1 \%$. Dust plumes were also visible while the van travelled in between cities although daytime observations do not allow the quantitative determination of the LR and PDR for elevated layers. Those cases will therefore not be included in the discussion.

\subsection{Origin of the elevated layers}

To identify the dust sources, Fig. 10 presents 7 -day backward trajectories ending in the dust layer observed west of Kazan (Sect. 4.1.1). The trajectories have been calculated using the Hybrid Single Particle Lagrangian Integrated Trajectory Model (HYSPLIT 4, http://ready.arl.noaa.gov/ HYSPLIT.php) under the isentropic mode for the vertical velocity. We used HYSPLIT in the ensemble mode, which is designed to assess the trajectory uncertainty by shifting the 


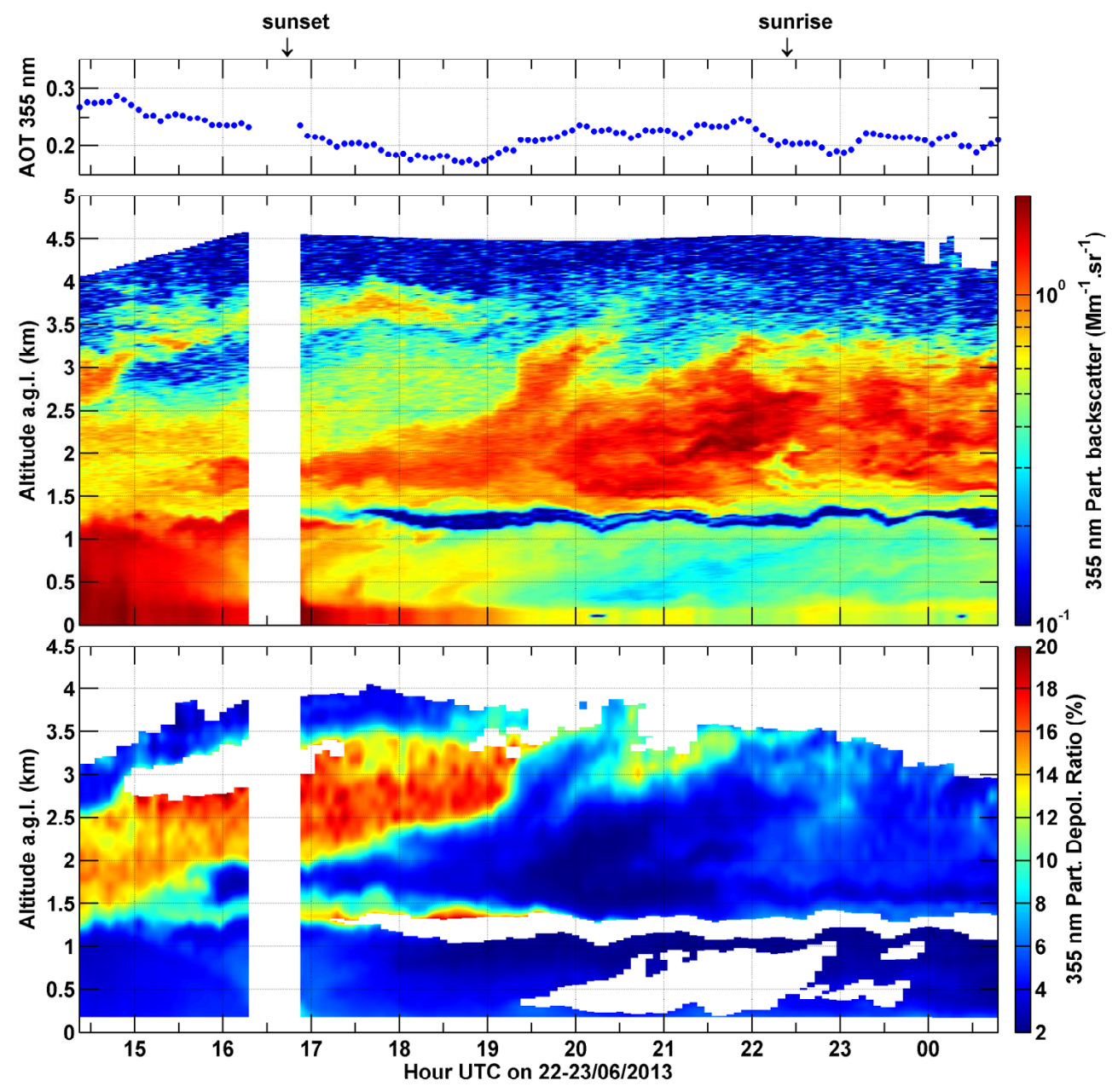

Figure 9. Aerosol optical thickness (AOT, top), backscatter (middle) and particle depolarization ratio (bottom) retrieved above Omsk during the night of 22-23 June 2013 as a function of UTC time and altitude above ground level (a.g.l.). Retrieval was made using a Klett inversion with the lidar ratio profiles from Fig. 8.

wind field at the ending point by one grid point in each of the three directions, giving 27 back-trajectories.

The fact that 20 of the back-trajectories do not enter the PBL during their journey shows that the air mass was mostly of free tropospheric origin, which is not surprising as MODIS already showed that the lidar sampled only the edge of the plume. Among the seven remaining backtrajectories, ground contact occurred in the northwestern and central parts of Kazakhstan, in the Volga mouth region (northwest bank of the Caspian Sea) and in the area between the Caspian and Aral seas. MODIS true colour reflectance (Fig. 10 background) shows that the Caspian-Aral region is a desert area, and geological maps available from the European Soil Portal (http://eusoils.jrc.ec.europa.eu/library/ esdac/index.html) confirm that large sandy areas stand at the south and east of the Aral Sea (Kyzylkum and Karakum deserts), and to a lesser extent at the northwest of the Caspian Sea. In the area between the Aral and Caspian seas, and also in large parts of central Kazakhstan, soils are of loamy type, even including clay deserts like in the Sahel (takyr) or salt deserts (solonchak). Conditions for dust lifting are thus gathered in this region.

To identify the origin of the biomass burning particles observed along with the dust, MODIS fire hotspots are also indicated in Fig. 10 (MCD14ML product from the University of Maryland; Giglio et al., 2006). Fires coinciding with the back-trajectories are located in the steppes near the western Russian-Kazakh border and to the northwest of the Aral Sea. Regarding the possibility of those particles to actually be anthropogenic pollution, the cities of Saratov $\left(51.5^{\circ} \mathrm{N}\right.$, $46^{\circ} \mathrm{E}, \sim 840000$ inhabitants $)$ and Volgograd $\left(49^{\circ} \mathrm{N}, 44^{\circ} \mathrm{E}\right.$, $\sim 1$ million inhabitants) could have contributed. However, only a more detailed backward dispersion study could confirm this and meanwhile, a wildfire burning origin remains much more likely.

Figure 11 displays a similar ensemble of HYSPLIT 7-day back-trajectories, but ending in the dust layer observed above Omsk. Those trajectories confirm that it has the same ori- 


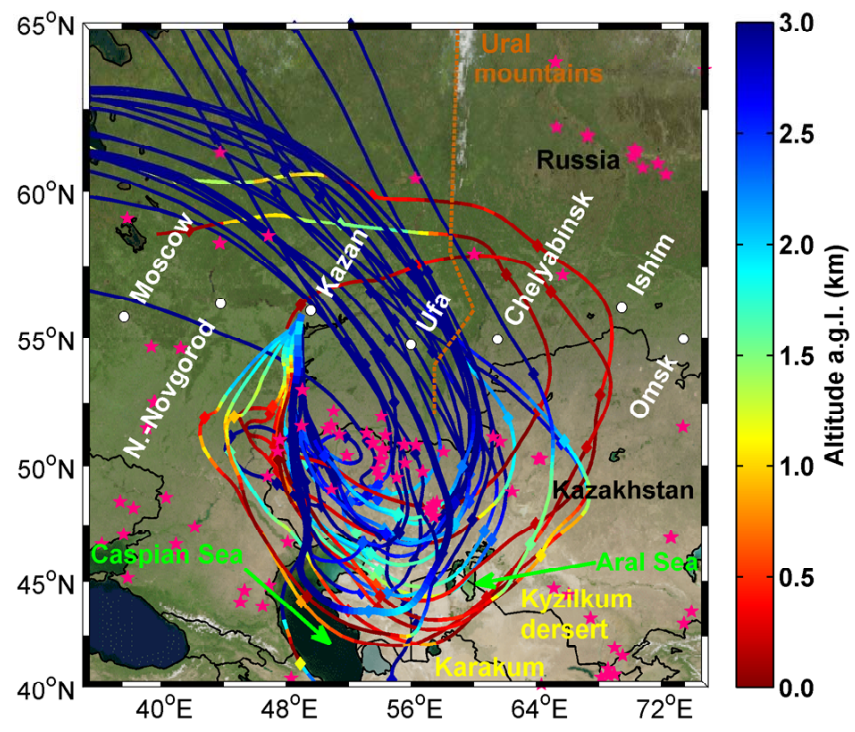

Figure 10. Seven-day back-trajectories ending in the dust layer observed west of Kazan city on 18 June 2013, computed using HYSPLIT Lagrangian model in single (bold line) and ensemble mode (thin lines). Trajectories are coloured following the altitude above ground level (a.g.l.): red parts correspond to ground contact. Ticks are spaced by $24 \mathrm{~h}$. Pink stars represent MODIS fire hotspots detected during the trajectories time period.

gin as the dust layer observed near Kazan 5 days earlier, i.e. the sandy/loamy soils of southwestern Kazakhstan. Incidentally, from Moscow (16 June) to Omsk (22 June), the van travelled eastwards at the same pace as a high-pressure system. As the winds curled around the anticyclone, air masses which had passed over the Caspian-Aral region were continuously brought up to the north, producing dust outbreaks over $2300 \mathrm{~km}$, from 38 to $73^{\circ} \mathrm{E}$. The weak and changing winds prevailing near the centre of the anticyclone are also responsible for the erratic shape of the early part of the trajectories.

The back-trajectories (not shown) ending in the biomass burning layer observed above Omsk a few hours later are very similar to those presented on Fig. 11. MODIS highlights three fire areas located in the steppes of northwestern Kazakhstan $\left(51^{\circ} \mathrm{N}-54^{\circ} \mathrm{E}, 50^{\circ} \mathrm{N}-56^{\circ} \mathrm{E}\right.$ and $\left.48^{\circ} \mathrm{N}-57^{\circ} \mathrm{E}\right)$ that had significant fire power ( 90 to $120 \mathrm{MW}$ ) and were overpassed at low altitude by the back-trajectories. Fire hotspots were also observed by MODIS in the wooded area located under the latest part of the back-trajectories $\left(60-62^{\circ} \mathrm{N}, 69-73^{\circ} \mathrm{E}\right)$. However, their fire radiative power is low (max. $38 \mathrm{MW}$ ) so that it is doubtful that the smoke was injected as high as the back-trajectories ( $\sim 2 \mathrm{~km}$ a.g.l.). However, larger fires might have escaped the eyes of MODIS as the back-trajectories travelled along the southern edge of a cloud system.

Back-trajectories ending above Nizhneudinsk (not shown) indicate that the air mass came from the forests areas of the

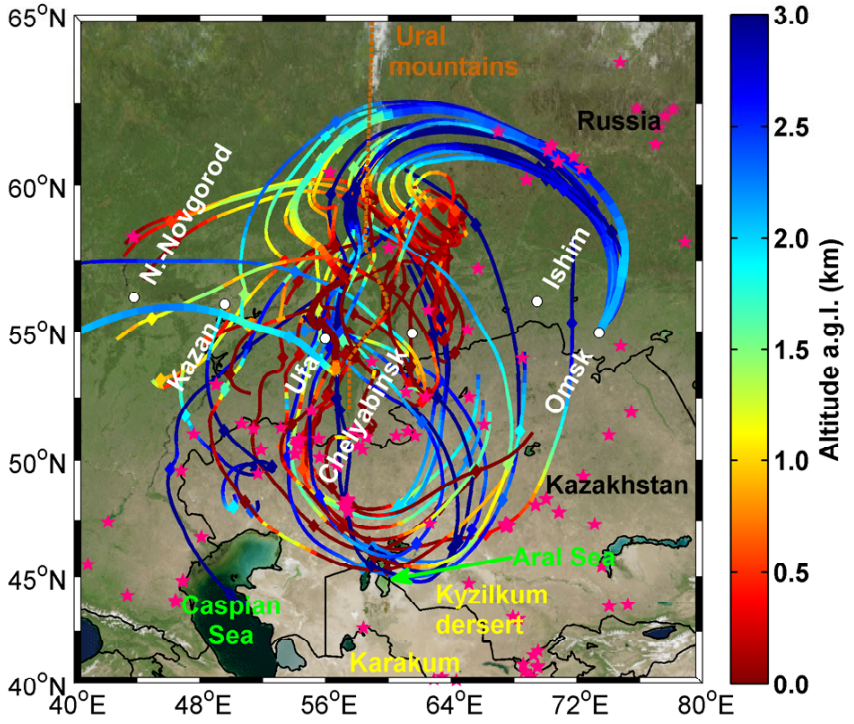

Figure 11. As Fig. 10, but with trajectories ending in the dust layer observed above Omsk city on 22 June 2013.

far north but a dense cloud cover blinded MODIS and prevented the identification of the aerosol sources.

\subsection{Discussion}

To summarize, LR and PDR values from the different case studies are recalled in the lower part of Table 1 (desert dust) and Table 2 (biomass burning), along with the references they can be compared with.

\subsubsection{Desert dust aerosols}

Particle depolarization ratio. The $23 \pm 2 \%$ PDR retrieved in the Kazan dust layer confirms it was pure desert dust. Indeed, it falls in between the two values reported in the literature for PDR at $355 \mathrm{~nm}$ which are $\sim 20 \%$ for Gobi desert dust advected over Tokyo (Murayama et al., 2004) and $25 \pm 6 \%$ in Saharan dust layers advected over Morocco and Cabo Verde during the Saharan Mineral dust experiments (SAMUM; Groß et al., 2011; Müller et al., 2012). For mixes of desert dust with biomass burning ("dusty mixes"), the values retrieved near Kazan $(13 \pm 3 \%)$ and above Omsk $(17 \pm 2 \%)$ are difficult to compare as the PDR strongly depends on the proportions of the aerosol mix. Values of $18 \pm 3 \%$ have been reported during SAMUM (Groß et al., 2011; Müller et al., 2012), whereas Chazette et al. (2014) found 16 to $19 \%$ in Saharan dust layers advected over the Balearic Islands during the Hydrological cycle in Mediterranean Experiment (HyMeX) campaign. Simultaneous observations at 355 and $532 \mathrm{~nm}$ during the SAMUM campaigns showed that the depolarization of desert dust aerosols increases with wavelength (Groß et al., 2011; Müller et al., 2012) so that the 28 to $35 \%$ PDR values reported at $532 \mathrm{~nm}$ by Burton et al. (2012) 
and Mamouri et al. (2013) cannot be compared directly to our Russian observations.

Extinction-to-backscatter (lidar) ratio. The $355 \mathrm{~nm} \mathrm{LR}$ values reported in the literature for pure desert dust range from $38 \pm 5 \mathrm{sr}$ for Saudi Arabian dust advected over the Maldives Islands during INDOEX (Müller et al., 2007) to $58 \pm 7 \mathrm{sr}$ for western Saharan dust during SAMUM (Müller et al., 2012). The observations during SAMUM also show a slight decrease of the lidar ratio from 355 to $532 \mathrm{~nm}$ (Müller et al., 2012). Indeed, the range of values at this wavelength is slightly lower, with 34 to $39 \mathrm{sr}$ for Syrian dust advected over Cyprus (Mamouri et al., 2013) and 44 to $51 \mathrm{sr}$ for an ensemble of airborne campaigns over North America and the Caribbean (Burton et al., 2012). The observations presented in this paper are therefore in good agreement, as we retrieved $43 \pm 14 \mathrm{sr}$ for pure desert dust (Kazan case) and $50 \pm 13 \mathrm{sr}$ for an aerosol mix containing a large fraction of dust, as indicated by its $17 \%$ PDR (Omsk case). Schuster et al. (2012) showed that the lidar ratio of desert dust has a strong geographic dependency, following changes in the mineralogical composition of the dust particles. Our observations correspond to the LR values retrieved in the Sahel by Schuster et al. (2012). Unfortunately we cannot relate it to the mineralogical composition of dust particles in the Caspian-Aral region, as we could not find information on that point. Regarding dusty mixes, the comparison is difficult as the LR, like the PDR, will strongly depend on the proportions of dust in the mix; one can just note that the $75 \pm 9$ sr retrieved in the dust-smoke mix west of Kazan are identical to the SAMUM observations (Groß et al., 2011).

\subsubsection{Biomass burning aerosols}

Particle depolarization ratio. During this campaign, aged smoke plumes of two origins were sampled: particles coming from fires in the steppes or forests of northern Kazakhstan/southern Russia have PDR values of 3 to $4 \%$, whereas particles coming from forest fires in Far North Siberia have a very low PDR of $\sim 1 \%$ (Nizhneudinsk case). In the literature, depolarization ratios for aged smoke are 4-9\% (Burton et al., 2012), $5 \pm 2 \%$ (Tesche et al., 2011) or $<5 \%$ (Müller et al., 2007), for measurements that were all performed at $532 \mathrm{~nm}$. No simultaneous observations of PDR at 355 and $532 \mathrm{~nm}$ exist for biomass burning aerosols, although measurement of a mixed smoke and dust layer suggest that the PDR does not vary much with wavelength (Groß et al., 2011). Therefore, the PDR values retrieved for smoke coming from Kazakhstan/southern Russia are in good agreement with the literature.

Particles from the Far North observed above Nizhneudinsk have a lower depolarization ratio than every observations reported. However, Nisantzi et al. (2014) showed that the depolarization of smoke layers strongly depends on their dust content, that will itself depend on the soil nature around the fire (as dust can be lifted by the eddies caused by the fire heat) and on the plume age (as the coarse dust particles will quickly fall out). This might explain why smoke from Kazakhstan, where the ground is semi-desert, exhibits a higher depolarization than smoke from northern Siberia. Besides, the low value of extinction in this plume indicates that the particle concentration is small, suggesting that, rather than the plume from a single large fire, this might result from a mix between smoke from several small scattered fires and biogenic aerosols (secondary organics) collected all along the air mass journey over the plains of northern Siberia.

Lidar ratio. Simultaneous observations at 355 and $532 \mathrm{~nm}$ showed a strong variability of the LR of biomass burning aerosols with wavelength (Müller et al., 2005; Murayama et al., 2004; Nicolae et al., 2013; Tesche et al., 2011) so our measurements will be compared preferentially with other observations at $355 \mathrm{~nm}$. Amiridis et al. (2005) report a large dispersion of $355 \mathrm{~nm}$ LR values, from 39 to $94 \mathrm{sr}$, based on statistics over 4 years of smoke plumes from Russia and Ukraine advected above Greece. Other observations generally display LR values in the lower range of this interval: $\sim 40 \mathrm{sr}$ in a Siberian plume advected over Tokyo (Murayama et al., 2004), $46 \pm 13$ sr in Siberian and Canadian plumes advected over Germany (Müller et al., 2005) and 32 to $48 \mathrm{sr}$ in plumes from Ukraine and Russia (Nicolae et al., 2013). However, $87 \pm 17 \mathrm{sr}(\sim 100 \pm 25 \mathrm{sr})$ have also been retrieved in an African smoke plume during SAMUM (AMMA) by Tesche et al. (2011) (Chazette et al., 2007). Three of our observations are in good agreement with those references, i.e. the cases from Ishim $(65 \pm 6 \mathrm{sr})$, Omsk $(76 \pm 10 \mathrm{sr})$ and Nizhneudinsk ( $63 \pm 15 \mathrm{sr})$. The $107 \pm 14$ sr observed west of Kazan is above all other observations but not incompatible with Amiridis et al. (2005) or Tesche et al. (2011) given the large uncertainty.

\section{Conclusions}

For 1 full month, a mobile $\mathrm{N}_{2}$-Raman and depolarization lidar probed aerosols along the $10000 \mathrm{~km}$ ride from Paris to Ulan-Ude $\left(2\right.$ to $\left.108^{\circ} \mathrm{E}, \sim 55^{\circ} \mathrm{N}\right)$. A systematic dataprocessing was performed on the $30 \mathrm{~min}$ average profiles: the Raman channel was used to constrain the average extinctionto-backscatter ratio (i.e. lidar ratio or LR) between 300 and $700 \mathrm{ma}$ a.g.l. The campaign average LR was found to be $63 \pm 17 \mathrm{sr}$ along the journey and $70 \pm 20 \mathrm{sr}$ in the isolated village of Istomino (Lake Baikal shore). The distribution of the LR and PDR values shows that aerosols in Europe are characterized by higher LR values (60-102 sr) and very low PDR $(<1 \%)$ both in cities and in the countryside, indicating the dominance of pollution aerosols. In Russia, the LR values are more variable (44-106 sr) and a clear distinction exists between the countryside (PDR $<1 \%$ as in Europe) and the cities (PDR $>2 \%$ ). The higher depolarization in Russian cities is likely due to the significant amount of terrigenous 
aerosols lifted by vehicles or by the wind from the roads and sidewalks that generally have a bad tarmac.

Fixed measurements were performed in the cities during the night stops and enabled the determination of LR profiles through a complete Raman inversion or a multi-layer constrained Klett inversion. Several events of biomass burning plumes were recorded during these nighttime observations, with LR values ranging from 63 to $107 \mathrm{sr}$ and PDR values of from 1 to $4 \%$. Desert dust layers were also observed, with LR (PDR) values of $43 \pm 14 \mathrm{sr}(23 \pm 2 \%)$ for pure dust and $75 \pm 9 \mathrm{sr}(13 \pm 3 \%)$ for a mixed dust and biomass burning layer. The back-trajectory analysis identifies the dust source in the region of the Caspian and Aral Seas (southwestern Kazakhstan), an area whose dust emissions had not been characterized so far. Moreover, dust layers were observed from Moscow to Omsk $\left(37-73^{\circ} \mathrm{E}, \sim 2300 \mathrm{~km}\right)$, demonstrating that the Caspian-Aral region can give birth to large dust events spreading over wide areas of Russia and lasting for several days. Such an event does not require special conditions but a regular anticyclone moving eastwards over northern Kazakhstan, meaning such dust spreading could happen regularly and contribute significantly to the aerosol budget in southern Russia.
This ground-based mobile campaign provides a unique picture of summer aerosols in areas where observations are usually scarce. Although it is only a snapshot and no climatology, these observations hold more representativeness for two reasons: first, the lidar instrument involved in this campaign enabled the determination of two intensive properties of the particles (LR and PDR) that do not depend on aerosol amounts. And secondly, the comparison with a multi-annual average of MODIS Terra observations showed that the AOT values observed during the campaign are representative of the aerosol loads existing over Europe and Russia in the absence of exceptional fire events. Only the area where the dust event took place stands out from MODIS multi-annual average; however, it offered the opportunity to characterize the unstudied desert dust from the Caspian-Aral region. 


\section{Appendix A: Details of the lidar ratio retrieval processes}

Raman inversion. To differentiate the optical depth profile provided by the Raman channel, we use a low-pass derivative filter the kernel of which is based on the first derivative of a Gaussian curve (ter Haar Romeny et al., 1993) as it allows a much better rejection of high frequencies, i.e. short-scale fluctuations in the extinction profile, than the more commonly used Savitzky-Golay filters or sliding window linear fit (the difference is around $30 \mathrm{~dB}$ ). To take into account the decrease of the signal-to-noise ratio (SNR) with increasing altitude, the filter width $\sigma$ is increased following a saturating exponential function $\sigma(z)=a+b \times(1-\exp (-z / 1.5))$ with $z$ the altitude above ground level (a.g.l.) in km. The effective vertical resolution of the retrieved extinction profile is defined as the inverse of the spatial cut-off frequency (i.e. the frequency at which the filter response reaches $1 / e$ of its maximum amplitude). With $a=3$ and $b=7$ (our standard set of parameters), the effective vertical resolution tends towards $200 \mathrm{~m}$ at $5 \mathrm{~km}$ a.g.l., while the pair $a=1$ and $b=24$ (which we use in low-SNR conditions) produces a coarser resolution profile $(\sim 500 \mathrm{~m})$.

Single-layer constrained Klett inversion. The Raman channel is used to determine the partial AOT between 300 (complete overlap) and $700 \mathrm{~m}$ a.g.l. (range limit) which is then used to constrain the LR used in the Klett inversion. The principle is the same as described in Royer et al. (2011), except that the convergence is not dealt with using a dichotomy algorithm. Indeed, due to the transmission by the upper layers, the partial AOT is not always a monotonic function of the LR. Instead, the extinction profile is inverted using $13 \mathrm{LR}$ values distributed from 10 to $130 \mathrm{sr}$, a range covering LR values observed in the literature for the main types of aerosols (Tables 1, 2 and 3). Then, the interval is narrowed between the two LR values that produce the best partial AOT and the process is repeated. After three iterations, the LR value giving the best agreement with the Raman constraint is chosen, the LR is known by $0.1 \mathrm{sr}$ and the agreement is better than $10^{-3}$, if a solution exists. According to the sensitivity study carried out by Royer et al. (2011), the main source of uncertainty on the LR value is the random detection processes. It leads to a relative error on the LR ranging between 4 and $18 \%$ (16 to $100 \%$ ) during nighttime (daytime) for AOT values ranging from 0.1 to 0.5 and with a SNR of 35 (10). For the lidar-derived AOT the relative uncertainty is between 4 and $16 \%$ (12 to $40 \%$ ) during nighttime (daytime) for the same SNR values.

Multi-layer constrained Klett inversion. When the Raman channel has a longer detection range than $700 \mathrm{~m}$ a.g.l. (during nighttime), the process described in the previous section can be applied over several successive layers. At first, the constraint zone is located just below the normalization zone, or just below the limit range of the Raman channel. The LR value giving the best agreement between the partial AOT from the Raman channel and from Klett's inversion is deter- mined and attributed to this layer. Then, the constraint zone is translated downwards and the process is repeated until reaching the ground level. Layers where the aerosol load is too small (average extinction coefficient lower than $0.02 \mathrm{~km}^{-1}$ ) are ignored and the LR from the layer located directly above them is kept. The constraint zone width is chosen between 200 and $900 \mathrm{~m}$, depending on the aerosol load. The case studies that will be presented in Sect. 4 show that this method gives similar results as the derivative Raman inversion, with the advantage of producing a smoother LR profile (no fluctuations in the layers with a low aerosol load).

\section{Appendix B: Uncertainties on the depolarization}

Apart from measurement noise, the sources of error on the retrieved PDR are (i) the uncertainty on the lidar ratio, (ii) the uncertainty on the gain ratio and (iii) the error on the crosstalk between the total and perpendicular polarization channels. The impact of the former is estimated using the uncertainty on the lidar ratio when it is known (i.e. for case studies) or by varying LR by an arbitrary $\pm 10 \mathrm{sr}$ as in Freudenthaler et al. (2009), which corresponds to a 48-68 sr interval, for the systematic processing. The second and third terms are assessed by varying both the gain ratio (by its observed variability) and the coefficients of the separating plates (measured in the lab) by $\pm 5 \%$. When considering the average PDR in a layer, like in Sect. 4.1, the atmospheric variability (measured as the vertical standard deviation) in the layer is added as a fourth source of error. The contributions are then combined through a quadratic sum.

The error on PDR estimated by the process explained above is computed by a Monte Carlo simulation of dummy lidar profiles with thin layers (scattering ratio between 1.02 and 1.2) in the noise conditions of each study (i.e. systematic processing, nighttime case study $50 \mathrm{~min}$ average and $5 \mathrm{~min}$ average). As an example, Fig. B1 shows the results of this simulation conducted in the conditions of the Kazan case study (50 min average after dusk), for a layer with a homogeneous PDR of 1 or $5 \%$, a scattering ratio from 1.02 to 1.2, and error on LR varying from 2 to $10 \mathrm{sr}$. The error on the gain ratio and on the coefficients of the polarization separation plates is fixed at $5 \%$ each. Note that because of the small number of average profiles and the remaining sunlight after dusk, the noise condition considered here represents a worst case for nighttime observations. We find that, given the chosen scattering ratio threshold of 1.05 , the relative uncertainty on the PDR is largely constrained by the one on the lidar ratio for PDR values of $5 \%$ and above and below $4 \mathrm{~km}$ a.g.l. because of the error on the gain ratio, this relative uncertainty is always at least $7 \%$. For very low PDR values, the absolute uncertainty mostly depends on noise conditions, but remains above $0.2 \%$. 

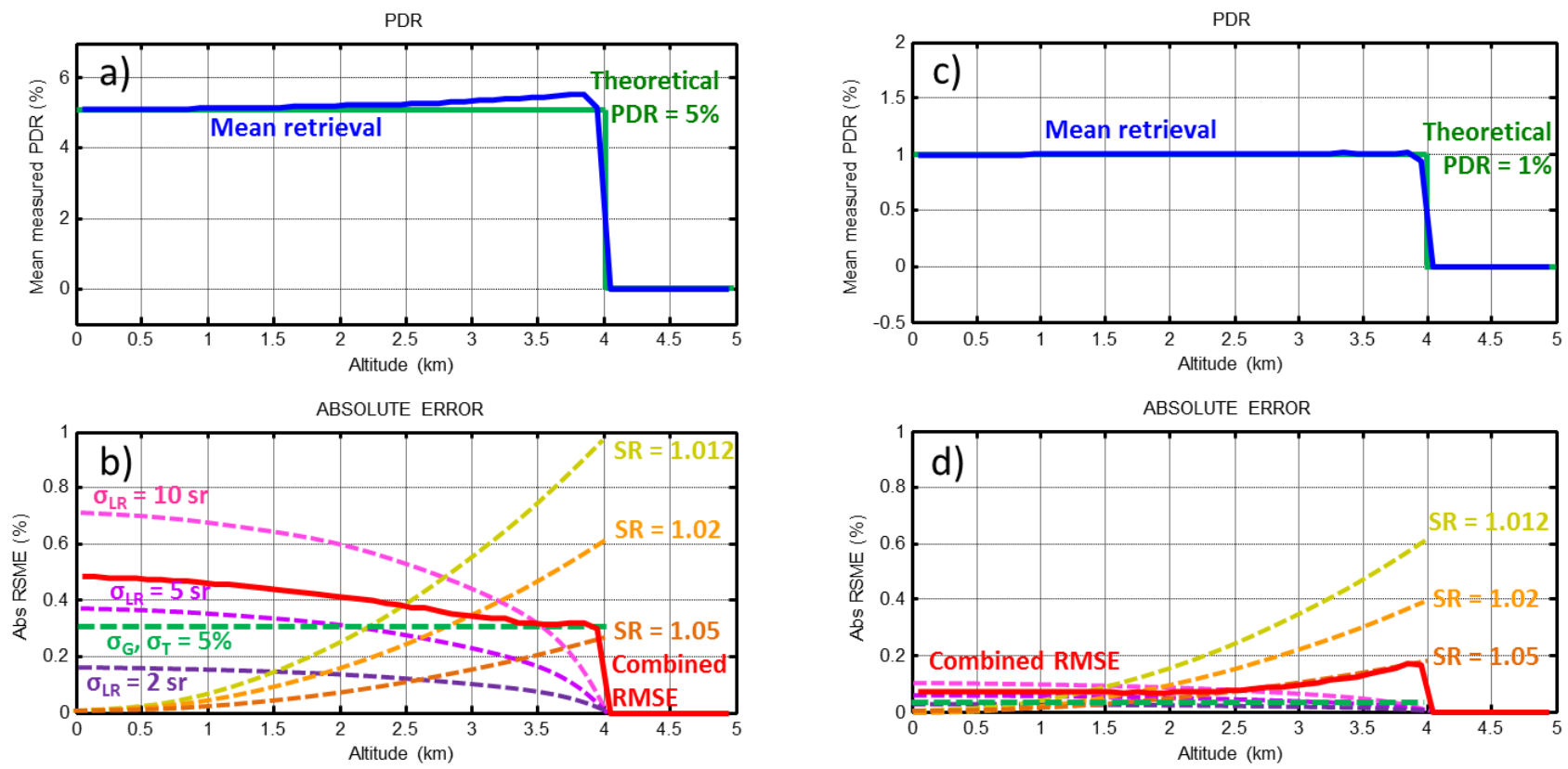

Figure B1. Monte Carlo simulation of error on PDR measurements in the noise conditions of the Kazan case study; (a) mean retrieval for dummy PDR profile of $5 \%$ from 0 to $4 \mathrm{~km}$ a.gl., (b) effects of error parameters and Monte Carlo simulated root-mean-squared error for a scattering ratio of 1.05 and an error on LR of $5 \mathrm{sr}$, (c) and (d) the same, for PDR $=1 \%$ from 0 to $4 \mathrm{~km}$. 
Acknowledgements. The authors would like to thank Frederik Paulsen, Honorary Consul for the Russian Federation in the canton of Vaud, Switzerland, both for his financial support and for obtaining the permission to operate in Russia. The authors are also very grateful to Alexander Ayurzhanaev from the Siberian Branch of the Russian Academy of Sciences, Laboratory of Physics of Atmospheric Processes, Ulan-Ude, for his vital help with the logistics of the journey while he was aboard the van. We also thank Yoann Chazette for his help during the trip. Finally, the authors thank Cyril Moulin, head of the Laboratoire des Sciences du Climat et de l'Environnement, for his support and assistance in the administrative part of the project.

Edited by: A. Petzold

\section{References}

Amiridis, V., Balis, D. S., Kazadzis, S., Bais, A., Giannakaki, E., Papayannis, A., and Zerefos, C.: Four-year aerosol observations with a Raman lidar at Thessaloniki, Greece, in the framework of European Aerosol Research Lidar Network (EARLINET), J. Geophys. Res., 110, D21203, doi:10.1029/2005JD006190, 2005.

Amiridis, V., Balis, D. S., Giannakaki, E., Stohl, A., Kazadzis, S., Koukouli, M. E., and Zanis, P.: Optical characteristics of biomass burning aerosols over Southeastern Europe determined from UVRaman lidar measurements, Atmos. Chem. Phys., 9, 2431-2440, doi:10.5194/acp-9-2431-2009, 2009.

Ansmann, A., Riebesell, M., and Weitkamp, C.: Measurement of atmospheric aerosol extinction profiles with a Raman lidar, Opt. Lett., 15, 746-748, doi:10.1364/OL.15.000746, 1990.

Ansmann, A., Engelmann, R., Althausen, D., Wandinger, U., Hu, M., Zhang, Y., and He, Q.: High aerosol load over the Pearl River Delta, China, observed with Raman lidar and Sun photometer, Geophys. Res. Lett., 32, 13815, doi:10.1029/2005GL023094, 2005.

Ansmann, A., Tesche, M., Seifert, P., Groß, S., Freudenthaler, V., Apituley, A., Wilson, K. M., Serikov, I., Linné, H., Heinold, B., Hiebsch, A., Schnell, F., Schmidt, J., Mattis, I., Wandinger, U. and Wiegner, M.: Ash and fine-mode particle mass profiles from EARLINET-AERONET observations over central Europe after the eruptions of the Eyjafjallajökull volcano in 2010, J. Geophys. Res. Atmos., 116, D00U02, doi:10.1029/2010JD015567, 2011.

Bates, T. S., Huebert, B. J., Gras, J. L., Griffiths, F. B., and Durkee, P. A.: International Global Atmospheric Chemistry (IGAC) Project's First Aerosol Characterization Experiment (ACE1): Overview, J. Geophys. Res., 103, 16297, doi:10.1029/97JD03741, 1998.

Burton, S. P., Ferrare, R. A., Hostetler, . A, Hair, J. W., Rogers, R. R., Obland, M. D., Butler, C. F., Cook, A. L., Harper, D. B., and Froyd, K. D.: Aerosol classification using airborne High Spectral Resolution Lidar measurements - methodology and examples, Atm. Meas. Tech., 5, 73-98, doi:10.5194/amt-5-73-2012, 2012.

Cattrall, C., Reagan, J., Thome, K., and Dubovik, O.: Variability of aerosol and spectral lidar and backscatter and extinction ratios of key aerosol types derived from selected Aerosol Robotic Network locations, J. Geophys. Res., 110, D10S11, doi:10.1029/2004JD005124, 2005.
Chazette, P., Randriamiarisoa, H., Sanak, J., Couvert, P., and Flamant, C.: Optical properties of urban aerosol from airborne and ground-based in situ measurements performed during the Etude et Simulation de la Qualité de l'air en Ile de France (ESQUIF) program, J. Geophys. Res., 110, 2206, doi:10.1029/2004JD004810, 2005.

Chazette, P., Sanak, J., and Dulac, F.: New approach for aerosol profiling with a lidar onboard an ultralight aircraft: application to the African Monsoon Multidisciplinary Analysis, Env. Sci. Tech., 41, 8335-8341, 2007.

Chazette, P., Raut, J.-C., Dulac, F., Berthier, S., Kim, S.-W., Royer, P., Sanak, J., Loaëc, S., and Grigaut-Desbrosses, H.: Simultaneous observations of lower tropospheric continental aerosols with a ground-based, an airborne, and the spaceborne CALIOP lidar system, J. Geophys. Res., 115, D00H31, doi:10.1029/2009JD012341, 2010.

Chazette, P., Dabas, A., Sanak, J., Lardier, M., and Royer, P.: French airborne lidar measurements for Eyjafjallajökull ash plume survey, Atmos. Chem. Phys., 12, 7059-7072, doi:10.5194/acp-127059-2012, 2012.

Chazette, P., Marnas, F., and Totems, J.: The mobile Water vapor Aerosol Raman LIdar and its implication in the frame of the HyMeX and ChArMEx programs: application to a dust transport process, Atm. Meas. Tech., 7, 1629-1647, doi:10.5194/amt-71629-2014, 2014.

Deuzé, J. L., Bréon, F.-M., Devaux, C., Goloub, P., Herman, M., Lafrance, B., Maignan, F., Marchand, A., Nadal, F., Perry, G., and Tanré, D.: Remote sensing of aerosols over land surfaces from POLDER-ADEOS-1 polarized measurements, J. Geophys. Res., 106, 4913-4926, 2001.

Franke, K., Ansmann, A., Müller, D., Althausen, A., Wagner, F., and Scheele, R.: One-year observations of particle lidar ratio over the tropical Indian Ocean with Raman lidar, Geophys. Res. Lett., 28, 4559-4562, 2001.

Franke, K., Ansmann, A., Müller, D., Althausen, D., Venkataraman, C., Shekar Reddy, M., Wagner, F. and Scheele, R.: Optical properties of the Indo-Asian haze layer over the tropical Indian Ocean, J. Geophys. Res., 108, 4059, doi:10.109/2002JD002473, 2003.

Freudenthaler, V., Esselborn, M., Wiegner, M., Heese, B., Tesche, M., Ansmann, A., Müller, D., Althausen, D., Wirth, M., Fix, A., Ehret, G., Knippertz, P., Toledano, C., Gasteiger, J., Garhammer, M., and Seefeldner, M.: Depolarization ratio profiling at several wavelengths in pure Saharan dust during SAMUM 2006, Tellus, Ser. B Chem. Phys. Meteorol., 61, 165-179, 2009.

Giglio, L., Csiszar, I., and Justice, C. O.: Global distribution and seasonality of active fires as observed with the Terra and Aqua Moderate Resolution Imaging Spectroradiometer (MODIS) sensors, J. Geophys. Res., 111, 2016, doi:10.1029/2005JG000142, 2006.

Groß, S., Tesche, M., Freudenthaler, V., Toledano, C., Wiegner, M., Ansmann, A., Althausen, D., and Seefeldner, M.: Characterization of Saharan dust, marine aerosols and mixtures of biomassburning aerosols and dust by means of multi-wavelength depolarization and Raman lidar measurements during SAMUM 2, Tellus, Ser. B Chem. Phys. Meteorol., 63, 706-724, 2011.

Heintzenberg, J., Birmili, W., Seifert, P., Panov, A., Chi, X., and Andreae, M.: Mapping the aerosol over Eurasia from the Zotino Tall 
Tower, Tellus B, 65, 20062, doi:10.3402/tellusb.v65i0.20062, 2013.

Holben, B. N., Eck, T. F., Slutsker, I., Tanré, D., Buis, J. P., Setzer, A., Vermote, E., Reagan, J. A., Kaufman, Y. J., Nakajima, T., Lavenu, F., Jankowiak, I., and Smirnov, A.: AERONET-A Federated Instrument Network and Data Archive for Aerosol Characterization, Rem. Sens. Env., 66, 1-16, d 1998.

Huebert, B. J., Bates, T., Russell, P. B., Shi, G., Kim, Y. J., Kawamura, K., Carmichael, G., and Nakajima, T.: An overview of ACE-Asia: Strategies for quantifying the relationships between Asian aerosols and their climatic impacts, J. Geophys. Res., 108, 8633, doi:10.1029/2003JD003550, 2003.

IPCC: The Physical Science Basis, Contribution of Working Group I to the Fifth Assessment Report of the Intergovernmental Panel on Climate Change, edited by: Stocker, T. F., Qin, D., Plattner, G.-K., Tignor, M., Allen, S. K., Boschung, J., Nauels, A., Xia, Y., Bex, V., and Midgley, P. M., Cambridge University Press, Cambridge, United Kingdom and New York, NY, USA, 2013.

King, M. D., Kaufman, Y. J., Menzel, W. P., and Tanré, D.: Remote sensing of cloud, aerosol, and water vapor properties from the moderate resolution imaging spectrometer (MODIS), IEEE T. Geosci. Remote, 30, 2-27, 1992.

Klett, J. D.: Lidar inversion with variable backscatter/extinction ratios, Appl. Opt., 24, 1638-1643, 1985.

Law, K. S., Stohl, A., Quinn, P. K., Brock, C., Burkhart, J., Paris, J.D., Ancellet, G., Singh, H. B., Roiger, A., Schlager, H., Dibb, J., Jacob, D. J., Arnold, S. R., Pelon, J., and Thomas, J. L.: Arctic Air Pollution: New Insights From POLARCAT-IPY, Bull. Am. Meteorol. Soc., 95, 1873-1895, doi:10.1175/BAMS-D-1300017.1, 2015.

Lebel, T., Parker, D. J., Flamant, C., Bourlès, B., Marticorena, B., Mougin, E., Peugeot, C., Diedhiou, A., Haywood, J. M., Ngamini, J. B., Polcher, J., Redelsperger, J.-L., and Thorncroft, C. D.: The AMMA field campaigns: multiscale and multidisciplinary observations in the West African region, Q. J. R. Meteorol. Soc., 136, 8-33,2010.

Mamouri, R. E., Ansmann, A., Nisantzi, A., Kokkalis, P., Schwarz, A., and Hadjimitsis, D.: Low Arabian dust extinction-tobackscatter ratio, Geophys. Res. Lett., 40, 4762-4766, 2013.

Mattis, I., Ansmann, A., Müller, D., Wandinger, U., and Althausen, D.: Multiyear aerosol observations with dual-wavelength Raman lidar in the framework of EARLINET, J. Geophys. Res., 109, 13203, doi:10.1029/2004JD004600, 2004.

Molina, L. T., Madronich, S., Gaffney, J. S., Apel, E., De Foy, B., Fast, J., Ferrare, R., Herndon, S., Jimenez, J. L., Lamb, B., Osornio-Vargas, A. R., Russell, P., Schauer, J. J., Stevens, P. S., Volkamer, R., and Zavala, M.: An overview of the MILAGRO 2006 Campaign: Mexico City emissions and their transport and transformation, Atm. Chem. Phys., 10, 8697-8760, doi:10.5194/acp-10-8697-2010, 2010.

Müller, D., Mattis, I., Wandinger, U., Ansmann, A., Althausen, D., and Stohl, A.: Raman lidar observations of aged Siberian and Canadian forest fire smoke in the free troposphere over Germany in 2003: Microphysical particle characterization, J. Geophys. Res., 110, 17201, doi:10.1029/2004JD005756, 2005.

Müller, D., Ansmann, A., Mattis, I., Tesche, M., Wandinger, U., Althausen, D., and Pisani, G.: Aerosol-type-dependent lidar ratios observed with Raman lidar, J. Geophys. Res., 112, 16202, doi:10.1029/2006JD008292, 2007.
Müller, D., Lee, K.-H., Gasteiger, J., Tesche, M., Weinzierl, B., Kandler, K., Müller, T., Toledano, C., Otto, S., Althausen, D., and Ansmann, A.: Comparison of optical and microphysical properties of pure Saharan mineral dust observed with AERONET Sun photometer, Raman lidar, and in situ instruments during SAMUM 2006, J. Geophys. Res., 117, 7211, doi:10.1029/2011JD016825, 2012.

Murayama, T., Müller, D., Wada, K., Shimizu, A., Sekiguchi, M., and Tsukamoto, T.: Characterization of Asian dust and Siberian smoke with multi-wavelength Raman lidar over Tokyo, Japan in spring 2003, Geophys. Res. Lett., 31, 23103, doi:10.1029/2004GL021105, 2004.

Nicolae, D., Nemuc, A., Müller, D., Talianu, C., Vasilescu, J., Belegante, L., and Kolgotin, A.: Characterization of fresh and aged biomass burning events using multiwavelength Raman lidar and mass spectrometry, J. Geophys. Res., 118, 2956-2965, 2013.

Nisantzi, A., Mamouri, R. E., Ansmann, A., and Hadjimitsis, D.: Injection of mineral dust into the free troposphere during fire events observed with polarization lidar at Limassol, Cyprus, Atm. Chem. Phys., 14, 12155-12165, doi:10.5194/acp14-12155-2014, 2014.

Panchenko, M. V, Zhuravleva, T. B., Terpugova, S. A., Polkin, V. V., and Kozlov, V. S.: An empirical model of optical and radiative characteristics of the tropospheric aerosol over West Siberia in summer, Atm. Meas. Tech., 5, 1513-1527, doi:10.5194/amt-51513-2012, 2012.

Pappalardo, G., Amodeo, A., Apituley, A., Comeron, A., Freudenthaler, V., Linné, H., Ansmann, A., Bösenberg, J., D’Amico, G., Mattis, I., Mona, L., Wandinger, U., Amiridis, V., AladosArboledas, L., Nicolae, D., and Wiegner, M.: EARLINET: towards an advanced sustainable European aerosol lidar network, Atmos. Meas. Tech., 7, 2389-2409, doi:10.5194/amt-7-23892014, 2014.

Paris, J.-D., Ciais, P., Nédélec, P., Stohl, A., Belan, B. D., Arshinov, M. Y., Carouge, C., Golitsyn, G. S., and Granberg, I. G.: New Insights on the Chemical Composition of the Siberian Air Shed from the YAK-AEROSIB Aircraft Campaigns, B. Am. Meteorol. Soc., 91, 625-641, 2010.

Raes, F., Bates, T., McGovern, F., and Van Liedekerke, M.: The 2nd Aerosol Characterization Experiment (ACE2): general overview and main results, Tellus B, 52, 111, doi:10.1034/j.16000889.2000.00124.x, 2000.

Ramanathan, V., Crutzen, P. J., Lelieveld, J., Mitra, A. P., Althausen, D., Anderson, J., Andreae, M. O., Cantrell, W., Cass, G. R., Chung, C. E., Clarke, A. D., Coakley, J. A., Collins, W. D., Conant, W. C., Dulac, F., Heintzenberg, J., Heymsfield, A. J., Holben, B., Howell, S., Hudson, J., Jayaraman, A., Kiehl, J. T., Krishnamurti, T. N., Lubin, D., McFarquhar, G., Novakov, T., Ogren, J. A., Podgorny, I. A., Prather, K., Priestley, K., Prospero, J. M., Quinn, P. K., Rajeev, K., Rasch, P., Rupert, S., Sadourny, R., Satheesh, S. K., Shaw, G. E., Sheridan, P., and Valero, F. P. J.: Indian Ocean Experiment: An integrated analysis of the climate forcing and effects of the great Indo-Asian haze, J. Geophys. Res., 106, 28371-28398, 2001.

Raut, J.-C. and Chazette, P.: Retrieval of aerosol complex refractive index from a synergy between lidar, sunphotometer and in situ measurements during LISAIR experiment, Atmos. Chem. Phys., 7, 2797-2815, doi:10.5194/acp-9-8617-2009, 2007. 
Royer, P., Raut, J.-C., Ajello, G., Berthier, S., and Chazette, P.: Synergy between CALIOP and MODIS instruments for aerosol monitoring: application to the Po Valley, Atm. Meas. Tech., 3, 893907, doi:10.5194/amt-3-893-2010, 2010.

Royer, P., Chazette, P., Lardier, M., and Sauvage, L.: Aerosol content survey by mini N2-Raman lidar: Application to local and long-range transport aerosols, Atm. Env., 45, 7487-7495, 2011.

Salomonson, V. V, Magner, T., Barnes, W., Montgomery, H., and Ostrow, H.: Moderate Resolution Imaging Spectrometer - A progress report (April 1989), in Quantitative Remote Sensing: An Economic Tool for the Nineties, Proceedings of IGARSS ' 89 and of the 12th Canadian Symposium on Remote Sensing, IEEE, New York, Vancouver, Canada, 2917-2921, 1989.

Schuster, G. L., Vaughan, M., MacDonnell, D., Su, W., Winker, D., Dubovik, O., Lapyonok, T., and Trepte, C.: Comparison of CALIPSO aerosol optical depth retrievals to AERONET measurements, and a climatology for the lidar ratio of dust, Atm. Chem. Phys., 12, 7431-7452, doi:10.5194/acp-12-7431-2012, 2012.

Ter Haar Romeny, B. M., Florack, L. M. J., Salden, A. H., and Viergever, M. A.: Higher order differential structure of images, in Information Processing in Medical Imaging, edited by: Barrett, H. H. and Gmitro, A. F., Springer, Berlin Heidelberg, 77-93, 1993.
Tesche, M., Ansmann, A., Müller, D., Althausen, D., Engelmann, R., Hu, M., and Zhang, Y.: Particle backscatter, extinction, and lidar ratio profiling with Raman lidar in south and north China, Appl. Opt., 46, 6302-6308, 2007.

Tesche, M., Groß, S., Ansmann, A., Müller, D., Althausen, D., Freudenthaler, V., and Esselborn, M.: Profiling of Saharan dust and biomass-burning smoke with multiwavelength polarization Raman lidar at Cape Verde, Tellus B, 63, 649-676, 2011.

Vautard, R., Menut, L., Beekmann, M., Chazette, P., Flamant, P. H., Gombert, D., Guédalia, D., Kley, D., Lefebvre, M.-P., Martin, D., Mégie, G., Perros, P., and Toupance, G.: A synthesis of the Air Pollution Over the Paris Region (ESQUIF) field campaign, J. Geophys. Res., 108, 8558, doi:10.1029/2003JD003380, 2003.

Welton, E. J., Campbell, J. R., Spinhirne, J. D., and Scott, V. S.: Global monitoring of clouds and aerosols using a network of micro-pulse lidar systems, in: Lidar Remote Sensing for Industry and Environmental Monitoring, in Proc. SPIE 4153, Lidar Remote Sensing for Industry and Environment Monitoring, edited by: Singh, U. N., Itabe, T., and Sugimoto, N., Sendai, Japan, 151$158,2001$.

Winker, D. M., Pelon, J. R., and McCormick, M. P.: The CALIPSO mission: spaceborne lidar for observation of aerosols and clouds, in: Proc. SPIE 4893, Lidar Remote Sensing for Industry and Environment Monitoring III, edited by: Singh, U. N., Itabe, T., and Liu, Z., Hangzhou, China, = 1-11, 2003. 